ECONOMIC INTERDEPENDENCE:

\title{
A DETERRENT TO SINO-AMERICAN ARMED CONFLICT
}

By

\author{
Nguyen Thi Bich Thuan
}

A thesis submitted in partial fulfillment of the requirements for the Masters of International Relations (MIR) Degree

Victoria University of Wellington

2013 


\begin{abstract}
This thesis is devoted to examine the impact of economic interdependence on the interstate relations between the United States of America and the People's Republic of China. Specifically, all three propositions emerging from the ongoing controversy over the economics-security nexus inclusive of "economic interdependence increases conflict", "economic interdependence decreases conflict" and "economic interdependence is irrelevant to conflict" shall be tested in an empirical analysis of SinoAmerican relationship.
\end{abstract}

Three significant findings have emerged. Firstly, strong economic ties have actually caused tensions between Washington and Beijing. However, these issues of great disputes are not strong enough to turn into a Sino-American war because both countries have gained tremendous benefits from their strong economic ties and are not willing to destroy the economic ties that lock them together. Secondly, it is undeniable that economic interdependence has greatly promoted peace and stability between Washington and Beijing. However, there are three grounds for skepticism. To begin with, leaders always put security concerns over the prospects for economic loss, especially in times of insecurity and vulnerability. Furthermore, it is not yet certain that the linkages between the two sides in different areas can guarantee peace between the two countries. Also, there is a little historical evidence to believe that economic interdependence alone can bring lasting stability in the international order. Thirdly, the third proposition 'economic interdependence is irrelevant to conflict" perfectly fits the Sino-American relationship. To start with, Washington and Beijing have used trade to maximize their national power not to suppress conflict. In addition, we should not limit the future of Sino-American 
relationship to the discussion of economic factors. Both sides have kept their relationship relatively stable not only because of strong economic ties but also other factors such as: the emergence of non-traditional threats and the mutual possession of nuclear weapons.

\section{ACKNOWLEDGEMENTS}

First and foremost, I would like to express my deepest appreciation to my supervisor of this research, Dr. Jim Rolfe for his valuable guidance and advice. Dr. Rolfe has inspired me greatly to work in this research. Dr. Jim Rolfe has showed me a great deal of concerning materials and introduced me to an economic expert.

In addition, I would like to thank Dr. Gary Hawke and Dr. Marc Lanteigne for their insightful comments and suggestions.

Finally, an honorable mention goes to the Central Commission for External Relations of the Communist Party of Vietnam for creating favorable conditions for me to participate into this MA course of International Relations. 


\section{TABLE OF CONTENTS}

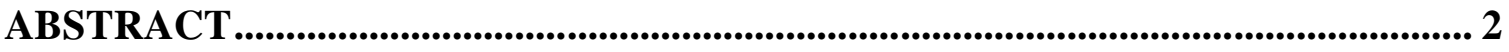

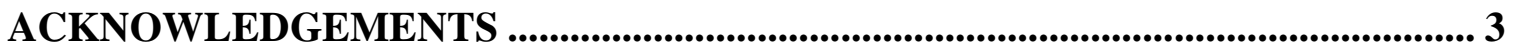

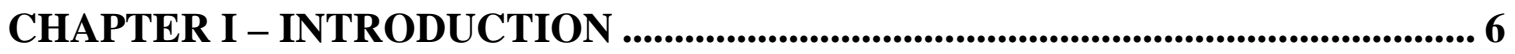

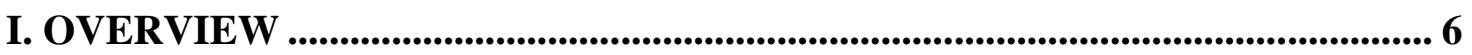

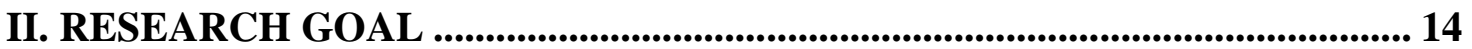

III. LITERATURE REVIEW ........................................................................... 14

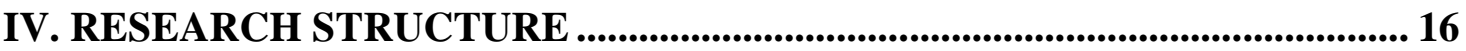

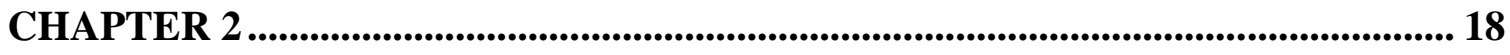

CONCEPTUALIZATION OF ECONOMIC INTERDEPENDENCE ....................... 18

THE ECONOMIC INTERDEPENDENCE-SECURITY NEXUS ............................. 18

I. CONCEPTUALIZATION OF ECONOMIC INTERDEPENDENCE ............... 18

1. Sensitivity/Vulnerability ................................................................................. 19

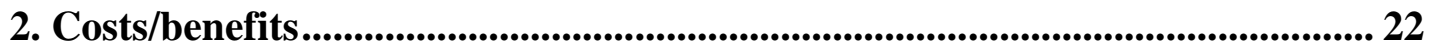

3. Salience/Symmetry .................................................................................................... 22

II. MEASUREMENT OF ECONOMIC INTERDEPENDENCE........................ 23

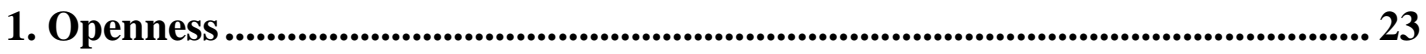

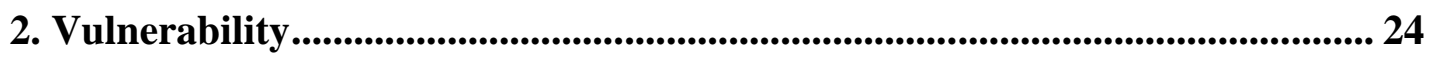

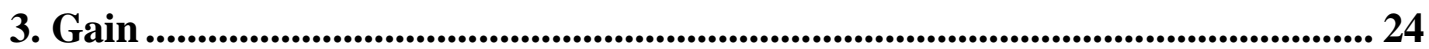

III. ECONOMIC INTERDEPENDENCE-CONFLICT RELATIONSHIP.......... 25

1. Economic Interdependence Increases Conflict ........................................... 25

2. Economic Interdependence Decreases Conflict .............................................. 26

3. Economic Interdependence is Irrelevant to Conflict ..................................... 29

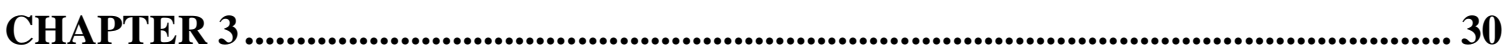

SINO-AMERICAN ECONOMIC INTERDEPENDENCE........................................ 30

RECENT SINO-AMERICAN TRADE DISPUTES............................................... 30

I. SINO-AMERICAN BILATERAL TRADE 1971-2012.................................... 30

1. China-US Trade Relations: 1971-1980............................................................... 31

2. China-US Trade Relation: 1981-1990 ................................................................... 32

3. China-US Trade Relation: 1991-2012 ............................................................ 34

II. AN OVERVIEW OF SINO-AMERICAN BILATERAL INVESTMENT ...... 36

1. US Investment in China ................................................................................... 36

2. Chinese Investment in the US ...................................................................... 38

III. RECENT SINO-AMERICAN TRADE DISPUTES ........................................ 39

1. Trade deficit ......................................................................................................................... 39 
2. Chinese Currency Valuation....................................................................................... 40

3. China's holding of US securities .................................................................................. 41

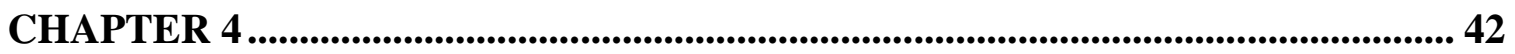

THE RELEVANCE OF THEORIES TO.............................................................. 42

SINO-AMERICAN ECONOMICS-SECURITY NEXUS ............................................. 42

I. PROPOSITION 1: TRADE INCREASES CONFLICT.......................................... 42

1. Argument 1: Both countries do not want to break their economic ties .......... 43

2. Argument 2: Concerns over Relative Gains Cannot Turn into a SinoAmerican Armed Conflict ................................................................................................ 45

II. PROPORSITION 2: TRADE DECREASES CONFLICT................................. 48

1. The relevance of five liberalist arguments to Sino-American economicssecurity nexus ................................................................................................................. 49

1.1. Argument 1: Trade decreases conflict because it is beneficial to all trading states

1.2. Argument 2: Trade decreases conflict because there is a strong desire to avoid conflict from the sub-systemic/domestic level.

1.3. Argument 3: Trade decreases conflict because it is a more efficient mean for creating wealth and influence ............................................................................ 51

1.4. Argument 4: Trade decreases conflict because the lost benefits associated with trade interruption are taken into leaders' calculation ...................................... 52

1.5. Argument 5: Trade decreases conflict because there are a convergence of national interest and spill-over effects. ..................................................................... 53

2. Grounds for skepticism ............................................................................................ 55

2.1. Argument 1: Leaders are not always deterred by the prospects of economic loss ................................................................................................................................ 55

2.2. Argument 2: Linkages cannot guarantee peace ............................................. 56

2.3. Argument 3: There is historical evidence that economic interdependence could not prevent war................................................................................................. 56

III. PROPOSITION 3: ECONOMIC INTERDEPENDENCE IS IRRELEVANT TO CONFLICT........................................................................................................... 57

1. Argument 1: Trade is meant for other purposes ................................................... 57

2. Argument 2: There are a great number of factors building up the SinoAmerican peace ............................................................................................................... 59

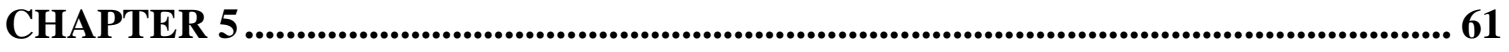

CONCLUSION AND POLICY IMPLICATIONS ........................................................ 61

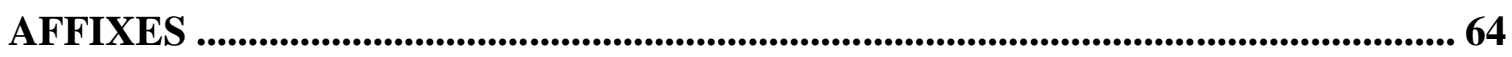

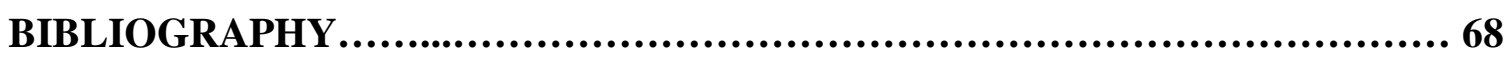




\section{CHAPTER I - INTRODUCTION}

\section{OVERVIEW}

An awareness that economic interdependence is essential to the survival and prosperity of states began to surface with the realization that countries had been tied closely together in a complex systemic web of interaction in which changes in one part could have direct or indirect consequences in other parts of the system ${ }^{1}$. The topic of economic interdependence, especially its virtues and vices has triggered considerable controversy among scholars of international relations.

Though varied, the core assumption of liberalists, mostly classical liberalists and liberal institutionalists is that economic interdependence provides a deterrent to armed conflict. Specifically, economic interaction creates new avenues for communication and avoids misunderstanding which may lead to conflict. Also, it creates a path toward stability and well-being ${ }^{2}$. On the other hand, skeptics, especially Marxist-Leninist and neo-realists, insist that economic interdependence either increases or is irrelevant to armed conflict ${ }^{3}$. In other words, economic linkages do not bring about pacifying effects on conflict but act as "a contributing factor in the impoverishment of some nations and tensions between other nations" or are "largely irrelevant to leaders' decisions to engage in, or refrain from, intense forms of interstate conflict" ${ }^{\prime 4}$

\footnotetext{
${ }^{1}$ Andrew, Little, Mann, Nicholson, Rosenau, Sylvester, Wallerstein, and Waever. 'International Theory: Positivism and Beyond' in Smith, Booth and Zalewski (ed.). Legacies. (Cambridge: Cambridge University Press, 1996), pp. 47-128, p. 77

${ }^{2}$ Barbieri, Katherine 'Economic Interdependence: A Path to Peace or a Source of Interstate Conflict?', Journal of Peace Research, Vol. 33, No. 1 (Feb., 1996), pp. 29-49, p.30-31

${ }^{3}$ Barbieri 'Economic Interdependence: A Path to Peace or a Source of Interstate Conflict?', p.32-33

${ }^{4}$ Barbieri, 'Economic Interdependence: A Path to Peace or a Source of Interstate Conflict?', p. 29.
} 
What is the impact of economic interdependence on the interstate relations between the United States of America and the People's Republic of China? For decades, states have clung to the hope that strong economic ties would facilitate the bonds of friendship, open up opportunities to socialize China and make it more ready to follow the status quo ${ }^{5}$ therefore, make war between these two highly interdependent Pacific nations unlikely to occur. Specifically, optimists argue that economic ties would bind Washington and Beijing in its web, hence, lead the two nations toward a cooperative and peaceful relationship ${ }^{6}$.

Nevertheless, as skeptics have pointed out, there is a little historical evidence to substantiate such a positive prospect. For example, Britain and Germany were major trading partners before the First World War. Their strong economic ties, however, failed to prevent the two countries from entering in one of the most disastrous wars in human history. In addition, as skeptics have insisted, trade cannot create a path toward stability and prosperity but serves as a source of insecurity. In fact, what brought Washington and Beijing together in the early 1970s was not economic interdependence but rather the military-strategic considerations. Furthermore, strong economic ties have indeed triggered a number of trade disputes between the two sides. Therefore, for skeptics, a high level of economic interdependence cannot ensure a future of stability and cooperation between these two great powers.

These two arguments have driven us to several questions: Given the dissolution of the Soviet Union in 1991 and the challenges of China economic rise to American superiority, what are the factors that bind the two Pacific nations closely together? More

\footnotetext{
${ }_{6}^{5}$ Kugler, Jacek and Tamen, Ronald. 'Regional Challenge: China's Rise to Power”, p.50

6 Chen-Yuan Tung, 'The Impact of Bilateral Economic Interdependence on US-China Relations'. http://www3.nccu.edu.tw/ ctung/Documents/W-B-a-7.doc (5 July 2013).
} 
importantly, is economic interdependence alone sufficient enough to create relative stability between these two most powerful nations? The purpose of this research is to address once again the impact of economic interdependence on Sino-American relationship because the topic of economics-security nexus is not only theoretically interesting but has important policy implications.

The economic rise of China has been one of the most important international relations story in the 21 st century. After roughly 150 years of being a weak player in the world, China is now emerging as the economic powerhouse of the world ${ }^{7}$. The seeds of China's economic miracle were first planted in 1978 when the government of China adopted a major program of economic reform after years of state control of all productive assets $^{8}$. As a result, China's rapid Gross Domestic Products (GDP) ${ }^{9}$ growth over the past three decades has been very impressive, averaging $9.8 \%$ annually from 1978 to $2009^{10}$. While pre-1978 China had seen an annual growth of $6 \%$ a year (with some painful ups and downs along the way), "post-1978 China saw an average real growth of more than 9 percent a year with fewer and less painful ups and down"11. Remarkably, the country enjoyed an increase of over $13 \%$ in several peak years ${ }^{12}$. More importantly, China's economic rise is impressive not only because of its speed of expansion but its growing

\footnotetext{
${ }^{7}$ Shirk, Susan., L. China: Fragile Superpower. (New York: Oxford University Press, 2007), p.4

${ }^{8} \mathrm{Hu}$, Zuliu and Khan, Mohsin, S. 'Why is China Growing So Fast? International Monetary Fund, Washington, D. C, 1997. http://www.imf.org/EXTERNAL/PUBS/FT/ISSUES8/INDEX.HTM (5 July 2013)

${ }^{9}$ The total market value of all the goods and services produced within the borders of a nation during a specified period.,

${ }^{10}$ Song, Liang. 'China's Rapid Growth and Development: An Historical and International Context' (2010). paftad.org/../02_SONG,\%20Ligang\%20-\%20Interl\%20dim\%20of\%20g (5 July 2013), p.7

${ }^{11} \mathrm{Hu}$ and Khan. 'Why is China Growing So Fast?

${ }^{12} \mathrm{Hu}$ and Khan. 'Why is China Growing So Fast?
} 
mass and enormous potential ${ }^{13}$. "Given the sheer size of its population and the rising productivity of its workers, China may one day regain its historic position as the world's largest economy"14. Actually, in 2010, China has become the world's second largest economy and most analysts predict that China will surpass the US as the world's biggest economy by 2050 and some as early as 2015 although it will not match the US in GDP per capita terms ${ }^{15}$.

The most reasonable explanation for the significance of China economic rise is, presumably, due to the assumption that its rise entails the decline of America ${ }^{16}$. Since the Cold War, the US has carried out its global commitment, which requires enormous resources, to secure peace and stability not only in its neighborhood but also other parts of the world, especially in Europe, Asia and Persian Gulf ${ }^{17}$. More remarkably, the US, during eight years under the Bush administration, pursued even more ambitious objectives of "waging wars in Iraq and Afghanistan, seeking to denuclearize North Korea and expanding America's military allies in Europe up to the borders of Russia" all at the same time ${ }^{18}$. As a result, "the ultimate foundation of America power-the relative superiority of the US economy in the world" has been in decline because of "the selfinflicted wounds of the Iraq War, growing government debt, increasingly negative current-account balancer and other internal economic weaknesses" ${ }^{19}$. For example, the average annual rate of US growth was at 3.7\% during Clinton's years and fell remarkably

\footnotetext{
${ }^{13}$ Friedberg, Aaron, L. 'The Future of US-China Relations: Is Conflict Inevitable?' International Security, Vol.30, No.2 (Autumn, 2005), pp. 7-45, p. 17

${ }^{14}$ Friedberg, 'The Future of US-China Relations: Is Conflict Inevitable?' p.17.

${ }^{15}$ Beckley, Michael. 'China's Century? Why America's Edge Will Endure', International Security, Vol. 36, No. 3 (Winter 2011/12), pp. 41-78, p.58.

${ }^{16}$ Pape, 'Empire Falls: First Draft of History'. The National Interest, January-February 2009, pp.21-34, p.21.

${ }^{17}$ Pape, 'Empire Falls: First Draft of History', p.21.

${ }^{18}$ Pape, 'Empire Falls: First Draft of History', p.21.

${ }^{19}$ Pape, 'Empire Falls: First Draft of History', p.21
} 
to $2.2 \%$ during eight years under Bush administration. This trajectory has observed even more negative signs due to the consequences of the 2008 financial crisis ${ }^{20}$.

A rising China, for realist pessimists, can be a troublemaker. In fact, we have seen that a wealthier China has strengthened its military capability. "China's military budget doubled from 1989 to 1994, and doubled again from 1994 to 1999, and again from 2005 to 2009,21 . China's expanding economy and growing military capabilities have driven the majority of realist pessimists to a conclusion that "it (China) is unlikely to behave differently than have others (rising powers) of its type throughout history" ${ }^{22}$. Specifically, emerging powers are usually not satisfied with their roles and status in the current system; therefore, tend to take steps to "secure their frontiers" and then "to reach out beyond them" by challenging "territorial boundaries, international institutional arrangement, and hierarchies of prestige"23. Meanwhile, dominant powers, feeling threatened by their challengers, are likely to employ force to prevent emerging powers before they achieve their full potential ${ }^{24}$. As a matter of fact, we have seen the increasing concerns aroused over China's upwardly mobility, for example, the assignment of strategic competitor role for China in several policy circles in Washington ${ }^{25}$. Moreover, although even American President Barack Obama wants “China's economy to continue to grow, its domestic demand to expand and its vitality to contribute to regional and

\footnotetext{
${ }^{20}$ Pape, 'Empire Falls: First Draft of History', p.24.

${ }^{21}$ Beckley. 'China's Century? Why America's Edge Will Endure', p.73

${ }^{22}$ Friedberg, 'The Future of US-China Relations: Is Conflict Inevitable?', p.20.

${ }^{23}$ Friedberg, 'The Future of US-China Relations: Is Conflict Inevitable?', p.19.

${ }^{24}$ Friedberg, 'The Future of US-China Relations: Is Conflict Inevitable?, p.20.

${ }^{25}$ Chan, Steve. 'Is there a Power Transition between the US and China? The Different Faces of National Power'. University of California Press. Vol. 45, No.5, September/October 2005, pp.687-701.
} 
global prosperity” ${ }^{, 26}$, a preventive war or even more insidious risk of over-stretch remain possible options for the $\mathrm{US}^{27}$.

However, a rising China is also important for American prosperity. Since the reestablishment of political and economic relations in the early 1970s, the two countries have gradually become trapped in a web of increasingly economic interdependence in which changes in one country can result in direct or indirect consequences in the other. For 22 years between 1949 and 1971, there was almost no trade between these two Pacific nations. The first efforts to re-establish the direct contacts between Washington and Beijing were undertaken in 1971. The renewal, however, was merely based on geopolitical considerations and driven by the complex relationship between US-Soviet Union and Soviet Union-China rivalries. As a result, during the first ten years of 1971-1980, business transactions between the two countries, though showed signs of improvement, remained extremely modest ${ }^{28}$. An outstanding illustration could be President Nixon's 1972 trip to China which was later described as the week changing the world, but which "produced virtually no effect on the stock market"29.

It was not until the late 1970 s with China's turning to market-oriented reforms that the country "has grown into one of the largest and most dynamic economies in the world" and "become the manufacturing workshop of the world" 30 , trade flows between Washington and Beijing advanced at breakneck pace ${ }^{31}$. However, a couple of decades after Deng's reform, the relationship was somewhat asymmetric in which China had

\footnotetext{
${ }^{26}$ Obama, Barack . 'US-China Policy Under an Obama Administration'. Amcham-China's China Brief, 2008, p.1

${ }^{27}$ Pape, 'Empire Falls: First Draft of History', pp.31-32.

Wang, Dong. 'China's Trade Relations with the United States in Perspective'. Journal of Current Chinese Affairs, Vol. 39. No.3, 2010, pp. 165-210.

${ }^{29}$ Wang. 'China's Trade Relations with the United States in Perspective', (p.166)

${ }^{30}$ Shirk. China: Fragile Superpower, pp. 15-16

${ }^{31}$ Wang. 'China's Trade Relations with the United States in Perspective', p.178.
} 
more to lose. It was not until after China was granted membership of the World Trade Organization that the country has become America's fastest growing export market with an average growth of $15 \%$ per annum ${ }^{32}$. Currently, China has been described as vital to American economic health because of its low-cost manufactured goods and the fact that it is now the biggest holder of US government debt ${ }^{33}$. In addition, there is no doubt that "American prosperity and global influence increasingly depend on decisions made in Beijing" 34 . Meanwhile, American investment is crucial to China because the country is China's important source of direct foreign investment, one of its largest investors and export markets. China needs a strong US economy because the slowdown in the US has severely affected China development ${ }^{35}$. Generally, the level of economic interdependence reaches to such a high level that their economies are interpreted as something symbiotic $^{36}$.

High levels of economic interdependence, according to liberalist scholars, have built up a great mutual interest in peace between Washington and Beijing. Specifically, economic linkages have already helped to remove several major disruptions, and are likely to tie the two countries closely, constrain and dampen any tendencies toward conflict $^{37}$. In fact, it is undeniable that economic interdependence plays an extremely important part in maintaining a relative peace between these two Pacific nations.

\footnotetext{
32 (2012). 'US Congressional District Exports to China: 2002-11 $112^{\text {th }}$ Congress'. The US-China Business Council. https://www.uschina.org/public/exports/2000_2011/files/US_Cong_Dist_Exports_2000-11.pdf (August 25, 2012)

${ }^{33}$ Ryan, Sean. 'Why is China so important to the U.S. economy?' Hubpages. http://kapitall.hubpages.com/hub/Why-is-China-so-Important-to-the-US-Economy (25 August 2012)

${ }^{34}$ Shirk. China: Fragile Superpower, p.249

${ }^{35}$ Chen, 'The Impact of Bilateral Economic Interdependence on US-China Relations'

${ }^{36}$ Young, Terry. 'US and China Economic Relationship at a Crossroad'. China US Focus, 2012. http://www.chinausfocus.com/slider/us-and-china-economic-relationship-at-a-crossroad/ (18 July 2013)

${ }^{37}$ Friedberg, 'The Future of US-China Relations: Is Conflict Inevitable?', p.12.
} 
On the whole, the burgeoning Sino-American economic relationship has had a positive effect on relations between the two countries. In the post-Cold War period, it has replaced the strategic cooperation between the United States and China against the Soviet Union that had provided the key foundation of US-China cooperation in the 1970s and 1980s. The two world economies have become increasingly interdependent ${ }^{38}$.

On the other hand, economic interdependence while helping to bind the two countries closely together, becomes a source of insecurity. "Most recent U.S. initiatives and complaints reflect a wide range of US interests and constituencies concerned with perceived unfair or disadvantageous aspects of the massive US-China economic relationship" 39 . Among these concerns, US trade deficit, Chinese currency valuation and China's holdings of US treasury securities have emerged as hints of serious economic dispute or confrontation.

The purpose of this research is to address a big question: Can economic interdependence deter Washington and Beijing from entering into an armed conflict? To be more specific, this research will test the impact of economic interdependence on SinoAmerican relationship. The three propositions about the economic interdependenceconflict relationship are examined. They are that: "interdependence increases conflict"; "interdependence decreases conflict"; and "interdependence is irrelevant to conflict".

To be more specific, three sub-questions are discussed in this research. Firstly, can economic ties create a path of stability and prosperity for Washington and Beijing? Secondly, is economic interdependence a source of insecurity which can spark a war between these two Pacific nations? Thirdly, is trade largely irrelevant to leaders' decisions to engage in, or refrain from, intense forms of interstate conflict?

${ }^{38}$ Sutter, Robert, G. US-Chinese Relation: Perilous Past, Pragmatic Present (Maryland: Rowman \& Littlefield Publisher, Inc, 2010), p.191

${ }^{39}$ Sutter. US-Chinese Relation: Perilous Past, Pragmatic Present, p.192 


\section{RESEARCH GOAL}

The principal purpose of this thesis is to examine the relevance of the three propositions about the economics-security nexus to the Sino-American relationship. A wide range of published works, therefore, shall be reviewed, analyzed and discussed to find out which proposition is the most relevant to Sino-American empirical study. The relationship between Washington and Beijing is special not only because they are the two largest economies in the world but also because they belong to the nuclear club. Given the complicated characteristics of this relationship, efforts to mention all aspects of economic and security dimensions would be too ambitious. This research, hence, will not discuss the challenges of China's rise to American dominance ${ }^{40}$. Also, it will not present security issues between the two sides ${ }^{41}$. It will focus and only focus on Sino-American economic interdependence and how it affects the security between these two powers. To be more specific, it will discuss in detail concept of economic interdependence, describe Sino-American remarkably strong economic interaction, examine the relevance of three propositions about the trade-conflict to Sino-American relationship, and explore several implications for both countries.

\section{LITERATURE REVIEW}

The concept of economic interdependence has triggered a considerable controversy among economists and scholars of international relations. The lack of conceptual clarity and even denial of any generally accepted definition ${ }^{42}$ have attracted a

\footnotetext{
${ }^{40}$ For additional information, see Beckley. 'China's Century? Why America's Edge Will Endure' and Pape, 'Empire Falls: First Draft of History'.

${ }^{41}$ For additional information, see Lawrence, Susan, V. 'US-China Relations: Policy Issues'. Congressional Research Service 7-5700 R41108 (2013).

${ }^{42}$ Baldwin, David, A. 'Interdependence and power: a conceptual analysis'. International Organization, Vol. 34, No. 4, Autumn 1980, pp.471-506
} 
number of researchers to conduct analyses on this concept, for example, Baldwin, Keohane and Nye, Barbieri, Mansfield and Pollins, and Crescenzi ${ }^{43}$. Despite the availability of conceptual analyses, the meaning of economic interdependence remains ambiguous or elusive, hence, there is a need to find out which one best describes the economic ties between Washington and Beijing.

In addition, a large number of studies such as those of Barbieri, Mansfield and Pollins and Ravenhill ${ }^{44}$ have mentioned the three propositions about the economic interdependence-conflict relationship. These studies provided detailed arguments put forward by the different schools of thought to prove their propositions. Given their strong focus on theories, these studies provided a comprehensive understanding of how different schools of international relations have explained the complicated relationship of economic interdependence and conflict. However, they failed to provide throughout researches of how these theories are applicable in reality.

Furthermore, not surprisingly, such a special relationship of Washington and Beijing has attracted quite a great number of scholars of international relations. In fact, the two dimensions of economics and security have received the most attention. Specifically, many scholars put great efforts in describing the economic relationship between the two Pacific nations as well as the tensions emerging from their strong trade

\footnotetext{
${ }^{43}$ Baldwin. 'Interdependence and power: a conceptual analysis'; Keohane, Robert, O. and Nye, Joseph S. Jr. 'Power and Interdependence'. Interdependence as an Analytic Concept. (Longman Classics and Political Science, 2001); Barbieri, Katherine. The Liberal Illusion: Does Trade Promote Peace? (University of Michigan Press, 2002); Mansfield, Edward, D. and Pollins, Brian, M. 'Interdependence and Conflict: An Introduction'; Crescenzi, Mark J. C. Economic Interdependence and Conflict in World Politics. (University of North Carolina, Chapel Hill, 2002)

${ }^{44}$ Barbieri, 'Economic Interdependence: A Path to Peace or a Source of Interstate Conflict?'; Mansfield, Edward, D. and Pollins, Brian, M. 'Interdependence and Conflict: An Introduction'; Ravenhill, J. 'Security Politics in the Asia-Pacific: A regional-global'. The economics-security nexus in the Asia-Pacific Region. (Cambridge: Cambridge University Press, 2009)
} 
linkages, for instance, Dumbaugh, Sengupta, Wang, Liew, and Morrison ${ }^{45}$. Additionally, several scholars tried to use the theories of economic interdependence to predict the future characteristics of Sino-American relationship, to name a few, Tellis and Will, Nye, and Friedberg ${ }^{46}$. However, there has not been yet any attempt to measure the level of economic interdependence between the two countries. Also, economic interdependence only makes up a small part in works studying the future of the Sino-American relationship. Moreover, there has been not yet any thorough scientific research focusing on testing all three propositions and their related arguments. This research, therefore, is the very first attempt to link the theoretical framework of economics-security to explain whether or not remarkably strong economic ties can lead to a stable relationship between Washington and Beijing.

\section{RESEARCH STRUCTURE}

Chapter 2 presents a detailed overview of the analytical framework of this thesis: the concepts of economic interdependence and conflict and the relationship between these two. Specifically, this chapter attempts to identify the best-fit definition of economic interdependence to Sino-American relationship. In addition, this chapter presents how different schools of thoughts in international relations put forward their arguments to explain the relationship between two dimensions of economics and security.

\footnotetext{
${ }^{45}$ Dumbaugh, Kerry. 'China-US Relations: Current Issues and Implications for US Policy'. Congressional Research Service, 2009, 7-5700, R40457; Sengupta, Jayshree. 'Economic Relations between the US and Two Asian Giants' in a Rasgotra, M. (ed). (New Delhi: Sage Publication, 2007); Wang. 'China's Trade Relations with the United States in Perspective'; ${ }^{45}$ Liew, Leong. H. 'US Trade Deficits and Sino-US Relations', Department of International Business \& Asian Studies, Griffith University, Queensland, Australia, 2010; and Morrison, Wayne M. 'China-US Trade Issues'. Congressional Research Service, 2013, 7-5700, RL 33536.

${ }^{46}$ Tellis, Ashley. J and Wills, Michael (ed.). 'Trade, Interdependence, and Security in Asia'. Strategic Asia 2006-07. (Washington: The National Bureau of Asian Research); Nye, Joseph, S., Jr. 'American and Chinese Power after the Financial Crisis'. The Washington Quarterly, Vol. 33, No. 4, 2010, pp.143-153; Friedberg, 'The Future of US-China Relations: Is Conflict Inevitable?, and Friedberg, Aaron, L. 'A Contest for Supremacy: China, America, and the Struggle for Mastery in Asia'. Roots of Rivalry (New York: W. W. Norton \& Company, 2011), pp. 36-58
} 
Chapter 3 is devoted to measure the level of economic interdependence between Washington and Beijing. Once again, this research shall use the theme of openness to measure Sino-American economic interdependence, focusing on two main indicators: trade and investment. Also, three trade disputes inclusive of American massive deficit with China, China's currency policy and China's holding of US securities shall be discussed in detail.

Chapter 4 examines the three propositions on economics-security nexus to the Sino-American relationship. Specifically, all related arguments emerging from the three propositions are to be tested to answer the research question: Can strong economic interdependence deter the two countries from entering into an armed conflict against each other?

Chapter 5 concludes what has been discussed in the research and investigates several implications for both countries given their high level of economic interdependence. 


\section{CHAPTER 2}

CONCEPTUALIZATION OF ECONOMIC INTERDEPENDENCE THE ECONOMIC INTERDEPENDENCE-SECURITY NEXUS

\section{CONCEPTUALIZATION OF ECONOMIC INTERDEPENDENCE}

The concept of interdependence has triggered a considerable controversy among economists and scholars of international relations. The lack of conceptual clarity and even denial of generally accepted definition ${ }^{47}$ have attracted a number of researchers to study on this topic.

Generally, most of scholars on all sides have ignored interdependence/mutual dependence distinction and they have used the two concepts almost interchangeably ${ }^{48}$. Keohane and Nye, for example, define dependence as "a state of being determined or significantly affected by external forces" while "interdependence, most simply defined means mutual dependence" 49 . In addition, Baldwin highlights that the differences between the two basic meanings of dependence are similar to those often made between sensibility interdependence and vulnerability interdependence ${ }^{50}$.

However, Katherine Barbieri objects to such usage of the two terms. For Barbieri, interdependence and mutual dependence mean differently to different people, therefore, should not be used to refer to the same phenomenon. She assumes only when there is presence of mutual needs, interdependence can emerge from dependence ${ }^{51}$. Nevertheless, given the importance of economic linkages to the survival and well-being of states in today's world, there is always presence of mutual needs. Therefore, there should not stress the distinction between interdependence and mutual dependence because if there

\footnotetext{
${ }^{47}$ Baldwin, David, A. 'Interdependence and power: a conceptual analysis'. International Organization, Vol. 34, No. 4, 1980, pp.471-506, pp.471-2

${ }^{48}$ Barbieri, Katherine. The Liberal Illusion: Does Trade Promote Peace? (University of Michigan Press, 2002), p.12

${ }^{49}$ Keohane, Robert, O. and Nye, Joseph S. Jr. 'Power and Interdependence'. Interdependence as an Analytic Concept. (Longman Classics and Political Science, 2001), p.7

${ }^{50}$ Baldwin. 'Interdependence and Power: a Conceptual Analysis', p.475

${ }^{51}$ Barbieri. The Liberal Illusion: Does Trade Promote Peace?, p. 13
} 
are differences, interdependence is more easily extended to a case where more than two economies are involved ${ }^{52}$.

Understanding such a complicated concept of interdependence needs more than a single definition, therefore, different aspects of this concept should be analyzed. As this writing is devoted to study the relationship between Washington and Beijing with a focus on their economic relations, the next section will discuss different dimensions of the concept with a strong interest in economic interdependence.

\section{Sensitivity/Vulnerability}

Baldwin presents two basic meanings of dependence. Firstly, dependence is used to refer to situations of being conditioned or seriously affected by external forces. Secondly, dependence refers to the relationship of subordination. In this second meaning, one needs the support or relies upon others in order to fulfill a need. Furthermore, as discussed, Baldwin also notes that while the first meaning of dependence corresponds to sensitivity interdependence, the later corresponds to vulnerability interdependence ${ }^{53}$.

These two basic meanings have been developed to propose a definition of economic interdependence as follows:

In the field of international relations, economic interdependence has two meanings. First, a group of country is considered interdependent if economic conditions in one are contingent on those found in the others....Second, countries are considered interdependent if it would be costly for them to rupture or forego their relationship ${ }^{54}$.

Moreover, after conducting a survey on how dependence has been conceptualized in two periods between 1568 and 1968 and from 1968 onwards, Baldwin comes to a conclusion that it is the second meaning or vulnerability interdependence which has been used in the common sense. In other words, vulnerability interdependence, defined as the opportunity $\operatorname{costs}^{55}$ of interrupting a relationship, represents normal usage by both economists and scholars of international relations ${ }^{56}$.

\footnotetext{
${ }^{52}$ Personal interview with Hawke, Gary, New Zealand Institute for Economic Research., 13 June 2013

${ }^{53}$ Baldwin. 'Interdependence and Power: A Conceptual Analysis', pp.476-489

${ }^{54}$ Mansfield, Edward, D. and Pollins, Brian, M. 'Interdependence and Conflict: An Introduction', p.11 www.press.umich.edu/pdf/0472098276-intro.pdf (2 July 2013)

${ }^{55}$ The loss of potential gain from other alternatives when one alternative is chosen.

${ }^{56}$ Baldwin. 'Interdependence and Power: A Conceptual Analysis', p.475.
} 
Hirschman does not define interdependence explicitly but figures out how a trade relationship would be translated into power and influence ${ }^{57}$. The two concepts of "gain from trade" and "dependence on trade", for Hirschman, should be viewed as the two aspects of the same phenomenon. The total gain from trade country B achieving from its trading relationship with country A reflects the total impoverishment or cost bear on country $\mathrm{B}$ in the event of trade termination between the two ${ }^{58}$. Hirschman even goes further by identifying two conditions in which country A may exercise its influence on its trading partner. Firstly, the cost of losing its total gain from trade needs to be high enough to ensure the compliance of country B to country A. Secondly, country A is able to find a substitute to replace country B in the event of trade termination ${ }^{59}$. Clearly, in his work, Hirschman does not refer to the first meaning but uses the second meaning to clarify the term of dependence as the opportunity costs of terminating a trading relationship ${ }^{60}$.

Baldwin's finding can be also exemplified by looking at Keohane and Nye's definition of interdependence. Specifically, Keohane and Nye discuss interdependence in two dimensions: sensitivity and vulnerability. The first dimension refers to situations in which a state is largely sensitive to changes in other countries while the second refers to its ability to compensate and rebound from those changes ${ }^{61}$. In other words, sensitivity interdependence answers two questions. Firstly, how long does it take for changes in one country to produce costly effects to its trading partners? Secondly, how significant are those costly effects? Meanwhile, the second dimension of vulnerability interdependence "rests on the relative availability and costliness of the alternatives that various actors face" ${ }^{e 2}$.

For example, country A and country B is immediately and seriously affected by increased oil price occurred in their oil exporter, country C. It then comes to a conclusion that both of them are sensitive to changes in country C. However, if A is able to find out the alternative market to replace $\mathrm{C}$ while $\mathrm{B}$ is unable to do the same thing, B is more vulnerable to A when referring to their trading relationship with $\mathrm{C}$.

\footnotetext{
${ }^{57}$ Crescenzi, Mark J. C. Economic Interdependence and Conflict in World Politics. (University of North Carolina, Chapel Hill, 2002), p.45.

${ }^{58}$ Baldwin. 'Interdependence and Power: A Conceptual Analysis', p.478

${ }^{59}$ Crescenzi. Economic Interdependence and Conflict in World Politics, p.45-6

${ }^{60}$ Baldwin. 'Interdependence and Power: A Conceptual Analysis', p.478

${ }^{61}$ Crescenzi. Economic Interdependence and Conflict in World Politics, p.49

${ }^{62}$ Keohane and Nye. 'Power and Interdependence', p.11
} 
Baldwin agrees that the two dimensions of interdependence need to be distinguished. However, he suggests using a less misleading term for sensitivity interdependence. In fact, he puts forward three strong arguments against maintaining the sensitivity/vulnerability distinction concerning the conventional usage of the term, possibility of factual misleading and the availability of other terms which can make desired distinction. ${ }^{63}$

To begin with, the first argument addresses the conventional usage of the term interdependence. Specifically, there is no need to maintain the sensibility/vulnerability distinction because scholars of international relations and even economists have used the term in the second meaning of vulnerability interdependence. As Baldwin concludes:

The works surveyed here suggest that the concept....has corresponded with "vulnerability interdependence" ${ }^{, 64}$.

From a conceptual standpoint the period since 1968 has contributed very little to thinking about international interdependence. Although scholars seem to vie with one another to invent yet another definition of "interdependence", the need for new concepts has not been demonstrated ${ }^{65}$.

And

Vulnerability interdependence has a superior claim to the mantle of conventionality, at least in international relations, and perhaps even in economics ${ }^{66}$.

Furthermore, the second argument against maintaining the distinction between sensitivity and vulnerability is the concern over the possibility of confusion. As Baldwin pointed out, sensitivity interdependence may be inversely related to its conventional usage. It is bad not to adopt the conventional usage and it is even worse to introduce a totally different new meaning for an old and frequently used concept. ${ }^{67}$

Finally, the most important argument highlights the availability of other terms. It is much better to use terms such as mutual responsiveness, mutual sensitivity or mutual influence to translate the idea of "the sensitivity of economic transactions between two or more nations to economic developments within those nations" ${ }^{\prime 68}$.

\footnotetext{
${ }^{63}$ Baldwin. 'Interdependence and Power: A Conceptual Analysis', p.490

${ }^{64}$ Baldwin. 'Interdependence and Power: A Conceptual Analysis', p.486

${ }^{65}$ Baldwin. 'Interdependence and Power: A Conceptual Analysis', p.489

${ }^{66}$ Baldwin. 'Interdependence and Power: A Conceptual Analysis', p.491

${ }^{67}$ Baldwin. 'Interdependence and Power: A Conceptual Analysis', p.491

${ }^{68}$ Baldwin. 'Interdependence and Power: A Conceptual Analysis', p.491
} 
In short, scholars on all sides of the arguments have noticed and well understood the differences between sensitivity and vulnerability for centuries. However, there is no need to distinguish interdependence into two dimensions because the sensitivity has been proved to be unclear and confusing. Sensitivity should be retained but it is necessary to change its name to something less misleading. Therefore, interdependence should be corresponded with its clear, time-honored and still useful dimension of vulnerability. ${ }^{69}$

\section{Costs/benefits}

Of a particular concern are costs and benefits in a trading relationship. States participate in trading transactions because of returned benefits. In other words, benefits must exist because they push states forward a trading relationship. The more states trade, the more easily they can be trapped in the web of economic interdependence. The denser the web is, the higher the costs of terminating such a trading relationship will be for involved states. To be more specific, costs and benefits emerge at the same time. The more a state gets from a trading relationship, the more it needs to pay in case of trade interruption $^{70}$. In addition, Keohane and Nye strongly emphasize the existence of costly effects to give rise to interdependence from international transactions- the flows of money, goods, people and messages. They also develop two perspectives for costbenefits analysis of an interdependent relationship with the first focusing on joint gains or joint losses of involved parties and the other concerning relative gains and distributional issues $^{71}$.

\section{Salience/Symmetry}

Barbieri categorizes interdependence into two dimensions: salience and symmetry. Salience refers to "the importance of a trading relationship, relative to other trading relationships" ${ }^{\prime 72}$. In other words, the significance of trade between two states needs not be identical to those conducted by one of them with other states. Accordingly, the salience of the economic relationship varies within dyads. Meanwhile, measuring symmetry allows us to find out whether or not partners are equally dependent on each

\footnotetext{
${ }^{69}$ Baldwin. 'Interdependence and Power: A Conceptual Analysis', p.492

${ }^{70}$ Crescenzi. Economic Interdependence and Conflict in World Politics, p.48

${ }^{71}$ For additional information, see Keohane, Robert, O. and Nye, Joseph S. Jr. 'Power and Interdependence'. Realism and Complex Interdependence. (Longman Classics and Political Science, 2001), pp. 20-32

${ }^{72}$ Barbieri. The Liberal Illusion: Does Trade Promote Peace?, p. 57
} 
other in a trading relationship. ${ }^{73}$ In addition, symmetry refers to the relative balance of economic interdependence. Meanwhile, asymmetry means the opposite. At one extreme, perfect symmetry (very rare) occurs when two trading partners are equally dependent upon each other. On the other hand, since perfect asymmetry (which does not occur in real life) exists in a trading dyad, one state is completely dependent on its partner while its partner has almost no dependence on the first state ${ }^{74}$.

More importantly, in international relations, states can get power if they are the less dependent actors. If two countries engage in a trading relationship and one is less dependent on another, the less dependent state has a source of power if both countries want to maintain their relationship ${ }^{75}$. "Manipulating the asymmetries of interdependence is an important dimension of economic power. Perfect symmetry is quite rare; so most cases of economic interdependence also involve a potential power relationship" ${ }^{\text {" }}$. Therefore, interdependence should not be limited to evenly balance mutual dependence because less dependent actors (the more powerful states) are very likely to use the power from asymmetric interdependence as a source of influence in dealing with another. ${ }^{77}$

\section{MEASUREMENT OF ECONOMIC INTERDEPENDENCE}

Although there are many ways to measure the level of economic interdependence, these measures usually emphasize one of the three themes: openness, vulnerability, or gain. While the indicators of openness and absolute gains have been employed by advocators of liberal theory, vulnerability and relative gains have been in favour by supporters of realist and neo-mercantilist arguments ${ }^{78}$.

\section{Openness}

"Openness indicators are based in one way or another on the ratio of trade to total economic output" ${ }^{, 79}$. This theme is based on the assumption that the more a state trades, the more it relies on an interdependent relationship because of the costly effects in the

\footnotetext{
${ }^{73}$ Barbieri. The Liberal Illusion: Does Trade Promote Peace?, p. 57

${ }^{74}$ Crescenzi. Economic Interdependence and Conflict in World Politics, p.52

${ }^{75}$ Nye, Joseph, S., Jr. 'American and Chinese Power after the Financial Crisis'. The Washington Quaterly, Vol. 33, No. 4, 2010, pp.143-153, p.147.

${ }^{76}$ Nye. 'American and Chinese Power after the Financial Crisis', p.147.

77 Keohane and Nye. 'Power and Interdependence', p. 9

${ }^{78}$ Mansfield and Pollins. 'Interdependence and Conflict: An Introduction', p. 11 and 16

${ }^{79}$ Mansfield and Pollins. 'Interdependence and Conflict: An Introduction', p.12.
} 
event of trade termination. Of the three themes, openness has been most widely employed to measure the level of economic interdependence. ${ }^{80}$

\section{Vulnerability}

Those who are in favour of the vulnerability theme often employ indicators of trade asymmetry to measure the level of economic interdependence. "Typically, such indicators are constructed using the portion of trade (imports and/or exports) between a given pair of states, $\mathrm{A}$ and $\mathrm{B}$, represented in a total trade of $\mathrm{A}$ and the total trade of $\mathrm{B}{ }^{, 81}$. Accordingly, the difference between two figures reflects the asymmetry in a trading relationship. ${ }^{82}$

\section{Gain}

The gain theme is different because it does not rely on the trade flows but the gains from trade to measure interdependence ${ }^{83}$. However, it is hard to measure gains from trade; therefore, it can only be measured indirectly by presuming "what total product would be if there was no cross-border trade" ${ }^{84}$. It is argued that the gains from trade can be collected by observing the import (or export) price elasticity which challenges scholars who are in favour of this theme because of the data's limited availability. ${ }^{85}$

Concerning this theme, there should be mentioned of absolute and relative gains. Absolute gain theory measures the total effects of an action. It is very much related to the positive-sum game which assumes that trade is beneficial to all involved parties. On the other hand, relative gains refer to the benefits a state gets compared to the other. The theory of relative gains relates to the zero-sum game which insists that states need to compete with others to gain more benefits ${ }^{86}$. Simply put, relative gains theory pays more attention to how the gains are shared, not the total gain available.

The problem of these measures is that they are heavily dependent on trade data which may not accurately reflect the level of interdependence. Although trade data is assumed to be highly correlated with other forms of economic exchange, its validity

\footnotetext{
${ }^{80}$ Mansfield and Pollins. 'Interdependence and Conflict: An Introduction', p. 12.

${ }^{81}$ Mansfield and Pollins. 'Interdependence and Conflict: An Introduction', p.12.

${ }^{82}$ Mansfield and Pollins. 'Interdependence and Conflict: An Introduction', p.12.

${ }^{83}$ Mansfield and Pollins. 'Interdependence and Conflict: An Introduction', p.12.

${ }^{84}$ Mansfield and Pollins. 'Interdependence and Conflict: An Introduction', p.12.

${ }^{85}$ Mansfield and Pollins. 'Interdependence and Conflict: An Introduction', p. 12.

${ }^{86}$ Cai, Feina. 'Absolute and Relative Gains in the Real World'. E-International Relations, 2011

http://www.e-ir.info/2011/04/28/absolute-and-relative-gains-in-the-real-world/ (16 July 2013)
} 
opens for question "especially in an era when merchandise trade composed a dwindling fraction of all economic exchange ${ }^{, 87}$. More importantly, in some cases, trade data can be fragmented and incomplete ${ }^{88}$. Furthermore, we have not known yet whether or not all aspects of economic interdependence such as commercial interdependence and monetary interdependence will have the same impact on conflicts ${ }^{89}$.

\section{ECONOMIC INTERDEPENDENCE-CONFLICT RELATIONSHIP}

There has been an increasing attempt to study the controversial relationship between conflict and economic interdependence. There are currently different clusters of opinion in the debate on whether or not economic interdependence creates stability or vulnerability in the international system. Despite variations in their arguments, the core assumption of liberal theorists claims that interdependence acts as a deterrent to conflict. On the other hand, the opponents of pessimistic-skeptical Marxism and realism are quite divided who insist that interdependence either increases or is irrelevant to conflicts. The following section will look at these three proportions of "Economic Interdependence Decreases Conflict", "Economic Interdependence Increases Conflict" and "Economic Interdependence Is Relevant to Conflict"

\section{Economic Interdependence Increases Conflict}

Skeptics have proposed two arguments to support the assumption that interdependence increases hostilities.

Firstly, the dependency and neo-Marxists schools of thought claims that "rather than increasing the prosperity of trading partners, trade often results in the impoverishment of less powerful nations" 90 . The core assumption of this dependency theory bases on trade imbalance between the developed (the core) and the developing (the periphery) countries in which "gains from trade are enjoyed exclusively by developed states.... and trade relegates powerless states to a position of dependence" ${ }^{91}$. In a trade asymmetry, the more dependent state is more likely to bear greater costs and

\footnotetext{
${ }^{87}$ Mansfield and Pollins. 'Interdependence and Conflict: An Introduction', p.14.

${ }^{88}$ Frensch, Richard, Hanousek, Jan, Kocenda, Evzen. 'Incomplete specialization and trade in parts and components', p.2.

${ }^{89}$ Mansfield and Pollins. 'Interdependence and Conflict: An Introduction', p.14.

${ }^{90}$ Barbieri, Katherine. 'Economic Interdependence: A Path to Peace or a Source of Interstate Conflict? Journal of Peace Research, Vol.33, No.1 (Feb., 1996), pp.29-49, p.32.

${ }^{91}$ Barbieri. 'Economic Interdependence: A Path to Peace or a Source of Interstate Conflict?, p.32.
} 
fewer benefits ${ }^{92}$. Accordingly, the power from asymmetric interdependence may be used by the less dependent state to coerce or manipulate their trade partners. Since extensive economic dependence poses challenges to the national autonomy and state sovereignty, it can trigger efforts to break the dependent ties ${ }^{93}$.

Secondly, the first argument connects us to the realism's skeptical attitude toward cooperation, the theory of relative gains. States, as claimed by realists, in anarchy fear that the benefits of joint gains that advantage a trading partner might produce a more dangerous potential enemy. Therefore, relative gains can inhibit cooperation ${ }^{94}$. More importantly, while relative gains may not matter when states trade with its allies or a relatively weak state, they do trigger considerable concerns when states trade with a relatively equal power or those who has the potential to become one ${ }^{95}$. In addition, in order to consolidate such a notion, neo-realists confirm that even in the presence of absolute gains, the benefits a state gets compared to others can dominate a rational leader' foreign policy behaviors. "Even when states are thought to benefit absolutely from trade, one state might consider its partner's disproportionate gain to be a loss to itself in terms of relative power. This is particularly the case when trading relations possess characteristics of cooperation as well as competition"96. Simply put, concerns over unequal gains from trade can turn into real challenge to national security ${ }^{97}$.

\section{Economic Interdependence Decreases Conflict}

Liberalist theorists hold a very positive view of economic interdependence. Upon the increasing trend of globalization in which no country can ever survive without opening up their economies, security interests have been replaced by economic interests that in turn, now is defined as a mean for wealth and prosperity. ${ }^{98}$ Economic interdependence, as claimed by liberalist scholars, lowers the possibility of war by increasing the value of trade over the alternative of aggression and making war too

\footnotetext{
${ }^{92}$ Barbieri. 'Economic Interdependence: A Path to Peace or a Source of Interstate Conflict?, p.32.

${ }^{93}$ Barbieri. 'Economic Interdependence: A Path to Peace or a Source of Interstate Conflict?, p.32.

94 Grieco, Joseph. M. 'Anarchy and the Limits of Cooperation: A Realist Critique of the Newest Liberal Institutionalism’. International Organization, Vol. 42, No. 3, Summer 1988, pp. 485-507, p.487.

${ }^{95}$ Islam, Akm, Khairul. 'The Post-Cold War US-China Relations: Win-Win or Zero-Sum Game, Asian Affairs, Vol.28, No. 2, April-June 2006, pp.24-45, p.28.

${ }^{96}$ Barbieri. The Liberal Illusion: Does Trade Promote Peace?, p.33

${ }^{97}$ Islam. 'The Post-Cold War US-China Relations: Win-Win or Zero-Sum Game', p.28.

${ }^{98}$ Crescenzi. Economic Interdependence and Conflict in World Politics, p.17
} 
costly. States, which assumed to be rational, therefore, should seek to avoid war and enhance trade with others to avoid the high opportunity cost of involving in wars.

Although liberalist scholars share a common positive perspective toward the linkage of trade to peace and prosperity, different strands of liberalism base on different dynamics to explain the complex nexus of interdependence and conflict. In fact, they have proposed five different arguments concerning the pacifying effects of trade on hostilities.

Firstly, optimists have assumed that states participate in trading activities voluntarily because trade benefits them all. States, for liberalist scholars, obtain benefits through exchanges and greater specification, therefore, become richer. To be more specific, trading activities provide states opportunity to exchange products by selling and buying things with lower prices, thus, gain revenue and boost consumption ${ }^{99}$. Furthermore, trade also helps states to specialize in goods and services which they hold comparative advantages ${ }^{100}$, therefore, increase states' economic efficiency. Overall, the most apparent outcome of economic is increased wealth for all. Due to the gains from trade, states shall avoid any possibility of conflict.

Secondly, another argument attributing the inverse relationship between trade and conflict studies this complicated relationship at domestic level. Of a particular interest, at sub-systemic level, is the pressure on governments by different actors who benefit from the increase in wealth from trade. These actors want their governments to peacefully resolve disputes with countries which they do business with. In other words, states are deterred from initiating conflict against a trading partner because "commercial openness generates efficiency gains that, in turn, render private traders and consumers dependent on foreign markets" ${ }^{101}$. On the one hand, beneficial actors seek to protect their gains from trade by encouraging governments to cooperate with other nations. On the other hand, public officials who seek to push up their country's economic performance and need such beneficial actors for political support have reason to accommodate their demands ${ }^{102}$.

\footnotetext{
${ }^{99}$ Barbieri. 'The Liberal Illusion: Does Trade Promote Conflict', p. 23

${ }^{100}$ The ability to produce goods and/or services at a lower opportunity cost than other's

${ }^{101}$ Mansfield, Edward D. and Pollins, Brian M. 'Interdependence and Conflict: An Introduction'. www.press.umich.edu/pdf/0472098276-intro.pdf (16 July 2013), p.3

${ }^{102}$ Mansfield \& Pollins. 'Interdependence and Conflict: An Introduction', p.3
} 
Thirdly, another argument supporting the pacifying effects of economic interdependence on conflict bases on an assumption that trade now plays an increasingly more efficient means for creating wealth and influence than the old method of military conquest and external expansion. In the current context, it is not land and raw materials which can guarantee a state's wealth and influence and it is "almost always cheaper in both financial and political terms to buy raw materials from other countries than to endure the international odium of mounting an invasion in order to seize them"103. Additionally, since the principal security concerns in the economic realm for most states shift from access to raw materials to access to markets, finance and technology, any temptation to use military force to secure the former will result in the potential loss of the latter $^{104}$.

Fourthly, optimists have also insisted that "intense conflict is deterred when leaders consider the welfare losses associated with an interruption to trade"105. The possibilities of intense form of conflict between major trading partners have lessened not because of the act of trade itself but the fear of losing the associated benefits. Specifically, the interruption of trade is assumed to lead to the loss of associated benefits emerging from a trading relationship. In addition, even in the absence of such loss, "it (conflict) will lead to inferior terms of trade, such as lower prices for exports and higher prices for imports" 106 . Therefore, in the policy-making process, it is no doubt that leaders will be very much affected by the calculation of benefits and costs from trade, especially with the most important trading partners.

Finally, liberalist theories have claimed that the expansion of interstate trading network is thought to improve communication across boundaries, "reduce misunderstanding and foster cultural and institutional mechanism capable of mediating conflicts of interest that do arise" ${ } 107$. Furthermore, as liberals, functionalists and neofunctionalists claim, interdependence is assumed to link and intertwine economic and political structures of states which results in the convergence of national interests and

\footnotetext{
103 'Human Security Report' (2009/10). Why International Wars are increasingly Rare, p.29

${ }^{104}$ Ravenhill, J. 'Security Politics in the Asia-Pacific: A regional-global'. The economics-security nexus in the Asia-Pacific Region. (Cambridge: Cambridge University Press, 2009)

${ }^{105}$ Barbieri. The Liberal Illusion: Does Trade Promote Peace?, p. 23

${ }^{106}$ Barbieri. The Liberal Illusion: Does Trade Promote Peace?, p. 24

${ }^{107}$ Barbieri. 'Economic Interdependence: A Path to Peace or a Source of Interstate Conflict?', p.31
} 
cultures. To be more specific, the stronger and closer commercial linkages among states are, the more cooperative they will be in other areas. As a result, there shall emerge a number of institutions, both formal and informal to foster trade and have spillover effects $^{108}$ in other fields ${ }^{109}$.

\section{Economic Interdependence is Irrelevant to Conflict}

A third type of argument is based on the realist skeptical view on the relevance of economic interdependence to war or peace. The core assumption of this realist theory is that the causes of war are political and military-strategic considerations rather than purely economic ones. Simply put, trade may serve as a mean to pursue the national interests which can easily be broken when states consider military conflicts options. While conflict originates from security-seeking or power-maximizing behaviors, peace can be achieved from the balance of power ${ }^{110}$. In other words, it is not economic but strategic concerns of "the balance of military forces, nuclear deterrence, the distribution of power, even advances in military technology" dominating leaders' calculation of the utility of conflicts $^{111}$. It does not mean that trade is not at of great important to realists. In fact, trade has been seen as the tool of influence. Moreover, strategic commodities provided from trade ties are of great important to states. However, when it comes to the question of conflict engagement, leaders may not pay special attention to the potential harm such a conflict may cause to a trading relationship. ${ }^{112}$

Simply put, discussions over the three proportions on economics-security nexus have provided us a much better understanding upon the impacts of economic interdependence on interstate relationship. The question now is: how are relevant theories to reality? The following chapters are meant to examine these theories to an empirical study of the Sino-American economics-security nexus.

\footnotetext{
108 The notion that integration between states in one economic sector will create strong incentives for integration in further sectors

${ }^{109}$ Barbieri. The Liberal Illusion: Does Trade Promote Peace?, pp.26-7

${ }^{110}$ Tellis, Ashley. J and Wills, Michael (ed.). 'Trade, Interdependence, and Security in Asia'. Strategic Asia 2006-07. (Washington: The National Bureau of Asian Research), p.3

${ }^{111}$ VanHook, Lauren. 'China in the Balance: Can Economic Interdependence Bring Stability to South Asia' www.moreheadstate.edu/uploadedFiles/Sites/Main_Sites/.../china.pdf (17 July 2013), p. 13

${ }^{112}$ Barbieri. The Liberal Illusion: Does Trade Promote Peace?, p. 37.
} 


\section{CHAPTER 3}

\section{SINO-AMERICAN ECONOMIC INTERDEPENDENCE RECENT SINO-AMERICAN TRADE DISPUTES}

As noted in Chapter 2, economic interdependence has been measured by different ways with an emphasis on one of three themes: openness, vulnerability and gain. Among these, openness has been most widely employed to measure the level of economic interdependence because of data availability and the assumption that the more a state trades, the more it relies on an interdependent relationship. This research, once again, shall use the theme of openness to measure the Sino-American economic interdependence, focusing on two main indicators: trade and investment. I found that Washington and Beijing have been locked into the so-called "balance of financial terror", a situation characterized by the fact that the US is Chinese largest export market and China is American largest creditor ${ }^{113}$. Moreover, a number of frictions have emerged along with their increasing mutually economic interdependence such as American large trade deficit with China, China's currency devaluation, China's holding of American securities, China's food safety, and WTO implementation issues, etc. The three first related issues shall be discussed in detail in this chapter.

\section{SINO-AMERICAN BILATERAL TRADE 1971-2012}

Despite its questionable validity, trade shall be used to measure economic interdependence between Washington and Beijing because it is the most traditional and most frequently used indicator of economic interdependence. Washington and Beijing traded for years before the establishment of the People's Republic of China in 1949. However, the Chinese communist revolution, the Korean War and American trade sanctions against China caused a massive reduction of business transactions between the two sides ${ }^{114}$. First steps to renew commercial activities between Washington and Beijing, notably the visit made by US President Richard Nixon, were traced back at the early 1970s after years of freezing. Bilateral trade, however, did not improve significantly

\footnotetext{
${ }^{113}$ Rajan, Ramkishen, S. and Beverinotti, Javier. 'China, Currencies and the Financial Balance of Terror'. Policy Brief Series, Issue 2, 2011, p. 1.

${ }^{114}$ Islam, Akm, Khairul. 'The Post-Cold War US-China Relations: Win-Win or Zero-Sum Game, Asian Affairs, Vol.28, No. 2, April-June 2006, pp.24-45, p.27.
} 
during the first ten years after the rapprochement (1971-1980) because China still closed its door to the world. Since 1978 with China's turning to market-oriented reforms, the two sides have been observing remarkably increasing economic interdependence. Total US-China trade rose from roughly \$ 2.3 billion in 1979 to $\$ 366$ billion in $2009^{115}$. "China is the US's second largest trade partner and the US is China's largest one...China is the US's largest source of trade deficit while the US is China's largest source of trade surplus" 116 . In the following section, I will discuss significant changes in Sino-American trade relationship in three periods: 1971-1980, 1981-1990 and 1991-2012.

\section{China-US Trade Relations: 1971-1980}

Efforts to re-establish direct contacts between the US and China were undertaken in 1971 with the removal of restrictions on US citizens visiting China, the ping-pong diplomacy with American table tennis player touring around China, and measures to lift restrictions on commerce and travel between the two countries. More remarkably, the elimination of trade embargo in June $10^{\text {th }} 1971$ and the United Nations General Assembly Resolution 2758 which brought China onto the Security Council in place of the Republic of China in Taiwan in October 1971 officially ended China's quarter century of isolation chiefly promoted by the US ${ }^{117}$.

However, there was little prospect of significant improvement in the bilateral trade between Washington and Beijing. China's market was described as illusory given the fact that this populated nation had a GNP ${ }^{118}$ only about $7 \%$ of that of the $\mathrm{US}^{119}$.

According to American figures ${ }^{120}$, their total bilateral trade stood at US\$4.7 million in 1971. Although there saw several ups and downs, generally, the overall picture reflected an upward trend in total trade flows between the two countries. By the year 1978, the total trade volume reached roughly US\$1,100 million. This hundred-time-

\footnotetext{
115 Wang, Dong. 'China's Trade Relations with the United States in Perspective'. Journal of Current Chinese Affairs, Vol. 39, No. 3, 2010, pp.165-210.

116 Xinchun, Niu. 'Sino-US Relations: Dependence and Fragility'. China Institutes of Contemporary International Relations, 2010. http://www.chinausfocus.com/library/think-tank-resources/china-lib/foreign_policy/cicir-sino-us-relationsdependence-and-fragility-february-2010/ (8 July 2013)

${ }^{117}$ Wang 'China's Trade Relations with the United States in Perspective', pp.169-170.

${ }^{118}$ GNP or "Gross National Product is the value of all the goods and services produced in an economy, plus the value of the goods and services imported, less the goods and services exported" http://economics.about.com/cs/economicsglossary/g/gross national.htm (10 July 2013).

${ }^{119}$ Wang 'China's Trade Relations with the United States in Perspective', p. 170

${ }^{120}$ See Table 1
} 
increase from a small base reflected a continued growth but still at a relatively low level in the total volume of trade between the two sides. The situation, though, changed significantly when the two countries finally normalized their diplomatic relations in January $1^{\text {st }} 1979$. Along with the full establishment of diplomatic relations, the two sides worked on removing the remaining legislative and administrative barriers to facilitate business transactions $^{121}$. As a result, a wide range of development was seen to encourage full trade normalization during the next 12 months inclusive of "a bilateral trade agreement; the opening of the first American law firm...in mainland China since 1950; US assistance with Chinese hydro-electronic power development, consumer goods manufacturing, and petroleum production and transportation; export-import bank credits; approval for expanded arms sales to China; and a Chinese commitment to exporting scarce strategic materials" 122 .

Simply put, as could be observed from tables 1 and 2, the first decade (19711980) possessed these following characteristics:

Firstly, business transactions between the two countries displayed signs of improvement but remained modest. Secondly, there was almost no correspondence between the figures recorded by the two countries, except for the last two years of the period (1979 and 1980). In addition, American trade with China never exceeded over 1\% of total US trade worldwide. Overall, the US had a trade surplus with China. Finally, the total trade conducted between the two sides was doubling each year during the last three consecutive years from 1978 to 1980 (according to American figures, total trade volume was US \$1,114.6 million, US \$2,316.3 million and US\$ 4,812 million in 1978, 1979 and 1980 respectively. According to Chinese figure, it was US \$991.70 million in 1978, US $\$ 2,451.60$ million in 1979 and US $\$ 4,811.27$ million in 1980). The figures could be seen as positive signs of a prosperous trading relationship later on between Washington and Beijing.

\section{China-US Trade Relation: 1981-1990}

The decade of 1981-1990 witnessed the initial phase of Chinese economic reform led by Deng Xiaoping and Zhao Ziyang. Reforms were carried out in agriculture, foreign

\footnotetext{
${ }^{121}$ Wang 'China's Trade Relations with the United States in Perspective', p. 172

${ }^{122}$ Wang 'China's Trade Relations with the United States in Perspective', p. 172
} 
policy, price system, non-state sectors, banking and financial sector, economic and social infrastructure and social welfare system ${ }^{123}$. This so-called second revolution made China a serious competitor and brought wealth into the country more than anytime since the foundation of the Republic of China in 1949. Notably, Chinese government encouraged foreign companies to invest into the country by giving general incentives such as tax reduction, flexible labor laws in special economic zones, etc ${ }^{124}$. Additionally, an important step to enhance Sino-American economic relations "was the steady liberalizing of controls over American exports of advanced technology. In 1980, such exports to China were reassigned from category $\mathrm{Y}$ (the Warsaw Treaty countries) to category $\mathrm{P}$ (new US trading partners, and then, in May 1983...to category V (American allies)"125. Moreover, in the 1970s, Chinese imports from the US were mainly iron and steel while the 1980s saw a diversification of products importing from the US including grain, chemicals and industrial raw materials, fertilizer, instruments and communications and transportation equipment, wood products, and chemical fibers. More remarkably, for the second half of the period, the US started to export finished manufactures and high-tech products to this giant market. Generally, both Washington and Beijing enjoyed benefits from their trading activities although trade with China was still very small for America ${ }^{126}$.

Overall, the period of 1981-1990 presented the following characteristics:

Firstly, as could be observed from tables 3 and 4, there was a great difference in the figures recorded by the two countries over the extent of China's exports. In 1990, for example, according to American figures, the US import from China was US\$ 15,233.9 million while the Chinese figure stood at only US\$ 6,580 million. More importantly, according to American figures, Washington has run a trade deficit with China since 1983 which has kept increasing over years. To be more specific, in 1983, Washington had a trade deficit with China at only US\$ 68 million. However, in 1990, only seven years later, the figure saw a massive increase of roughly 150 times to US\$ 10,416.6 million. Nevertheless, China figures showed the otherwise. China had a trade deficit instead of

${ }^{123}$ Chow, Gregory, C. 'Economic Reform and Growth in China'. Annals of Economic and Finance, Vol.5, 2004, pp. 127-152.

${ }^{124}$ Sengupta, Jayshree. 'Economic Relations between the US and Two Asian Giants' in a Rasgotra, M. (ed). (New Delhi: Sage Publication, 2007), pp.103-120

${ }^{125}$ Wang 'China's Trade Relations with the United States in Perspective', p.177

${ }^{126}$ Wang 'China's Trade Relations with the United States in Perspective', p. 177 
trade surplus with the US. There are technical and non-technical explanations for such a great difference ${ }^{127}$. However, of a particular concern was the fact that the statistical differences led to increasing frictions later on between the two countries ${ }^{128}$.

Both sides in the 1980s recognized the rapid growth that had taken in their commercial relationship since the establishment of diplomatic relations in 1979-an annual average growth rate of $44 \%$. The controversy over bilateral trade imbalance calls for an analysis of a complex array of local, regional and international factors. The disagreements over the size and causes of deficit originated in a number of areas: the two sides' different accounting approaches to re-exports to and from China via Hong Kong; US policy constraints on exports to china; the role of foreign firms in China; the multinational trade in commercial services; and global outsourcing and capital flows in the increasingly interdependent East Asian and world economy ${ }^{129}$.

Secondly, while trade with China from 1971 to 1980 never amounted to more than $1 \%$ of total US trade worldwide, the percentage doubled from $1.1 \%$ in 1981 to $2.2 \%$ in 1990. These figures showed that the two countries became increasingly interdependent in that period. Moreover, while the Sino-American rapprochement had no immediate impacts on the bilateral trade during the first decade (1971-1980), things changed remarkably and "economic factors had assumed a weight that both sides could no longer discount" $" 130$.

\section{China-US Trade Relation: 1991-2012}

There have been a great deal of changes during the last two decades, notably, the dissolution of the Soviet Union (1991), China accession to WTO (2001), 9/11 event (2001) and the global economic downturn (2008). The post-1992 was also known as the time of deep reform of Chinese economy under Juang Zemin. With a remarkable economic growth rate of China, especially since the country was granted WTO membership in 2001, the trade relationship between Washington and Beijing became much stronger despite a setback in 1990s. With the collapse of the common threat of the Soviet Union, there were no geo-strategic reasons to sustain cooperation between Washington and Beijing ${ }^{131}$. "But even at the time when the economic relations were at

\footnotetext{
${ }^{127}$ Martin, Michael, F. What's the Difference? Comparing US and Chinese Trade Data. Congressional Research Service, CRS Report for Congress, 2013.

${ }^{128}$ Wang 'China's Trade Relations with the United States in Perspective', p.179.

${ }^{129}$ Wang 'China's Trade Relations with the United States in Perspective', p.180.

${ }^{130}$ Wang 'China's Trade Relations with the United States in Perspective', p. 181.

${ }^{131}$ Islam. 'The Post-Cold War US-China Relations: Win-Win or Zero-Sum Game', p.25
} 
low ebb, trade volume rose despite of frictions and disputes" ${ }^{132}$. More importantly, by 2005, the center of Asian regional production network "had completely shifted to China, pushing the United States and Japan to the periphery. China became the core market for immediate products, from which final consumption goods were produced for export to the United States and to European countries" ${ }^{133}$. Moreover, the production systems in the Asia-US region has been characterized by structural diversity and a high degree of complementarity in which American economy is matured and advanced while China which specializes on low-skill jobs, is definitely not in the same camp of development. This complementarity serves as both cause and a result of deepening economic ties between countries in Asia inclusive of China and Asia power of the US ${ }^{134}$.

This period (1990-2012) suggested the following trends. Firstly, the collected data reflected growing interdependence between the two largest economies in the world. Trade with China, during this period, took up a considerable portion of total US trade worldwide, up to $14 \%$ in 2009 , showing the growing importance of China to the US market. Secondly, "since joining WTO in 2001, China's international exports have increased more rapidly than its exports to the US"135. This trend not only reflected China's tendency to diversify its markets but also its avoidance of being heavily dependence on the US market ${ }^{136}$. Thirdly, of a particular concern was the alarming trade deficit between the two countries. As presented in Table 5 and 7, the US ran a trade deficit with China which accelerated from US\$ 12.7 billion in 1991 to US\$ 311.053 billion in 2012, roughly 30 times increase over two decades.

In summary, first steps to renew the commercial activities between the US and China were taken in early 1971. The re-establishment with China was merely based on geo-political considerations and driven by complex relationship between US-Soviet Union and Soviet Union-China rivalries. However, after 10 years since re-establishment,

\footnotetext{
${ }^{132}$ Sengupta. 'Economic Relations between the US and Two Asian Giants', p. 104

${ }^{133}$ World Trade Organization, 'Trade Patterns and Global Value Chains in East Asia: From Trade in Goods to Trade in Tasks', p.74.

${ }^{134}$ World Trade Organization, 'Trade Patterns and Global Value Chains in East Asia: From Trade in Goods to Trade in Tasks', pp. 60-70

${ }^{135}$ Wang 'China's Trade Relations with the United States in Perspective', p.185

${ }^{136}$ Wang 'China's Trade Relations with the United States in Perspective', p.188
} 
the situation changed remarkably in which economic factors had assumed a weight that both sides could no longer discount. At first, China was much more dependent on the US market for its economic growth. Along with its comprehensive reforms, especially since it joined the WTO in 2001, the economic interdependence between the two sides has been observed increasing at remarkably high speed. All collected data have shown the increasing importance of Washington to American prosperity in recent decades. Currently, there is no doubt that "American prosperity and global influence increasingly depend on decisions made in Beijing" ${ }^{\prime 137}$. One of the most significant characteristics of Sino-American trade relationship, perhaps, is a steadily growing trade imbalance between these two Pacific nations. "Initially the balance in China's favor was small, but it now constitutes US's single largest bilateral trade deficit"138. There are different explanations for this growing imbalances ${ }^{139}$ and Chinese currency policy, which shall be discussed in detail later on, has been blamed as one of them.

\section{AN OVERVIEW OF SINO-AMERICAN BILATERAL INVESTMENT}

\section{US Investment in China}

Since China has carried out major economic reforms, there saw a massive increasing number of American companies hurried to set up business in this giant market either by forming joint-ventures with a Chinese company or a government agency ${ }^{140}$. "Early participants included H. J. Heinz; R. J. Reynolds Tobacco; Coca-cola; American Express; American Motors; AMF, Inc.; General Foods; Beatrice; Gillette; Pepsi-Cola; Eastman Kodak; AT\&T; Nabisco; and Bell South" ${ }^{\text {141 }}$. American companies' cumulative

\footnotetext{
${ }^{137}$ Shirk. China: Fragile Superpower, p. 249

${ }^{138}$ Lardy, Nicholas, R. 'China: The Great New Economic Challenge?' www.piie.com/publications/chapters_preview/3802/4iie3802.pdf(9 July 2013), p.126

${ }^{139}$ For additional information, see Lardy. 'China: The Great New Economic Challenge?'

${ }^{140}$ Wang 'China's Trade Relations with the United States in Perspective', p. 177

${ }^{141}$ Wang 'China's Trade Relations with the United States in Perspective', p. 178
} 
direct investments in China, through the end of 2013, made roughly US\$ 45 billion, which was far more remarkable than those of any other emerging markets ${ }^{142}$.

China has received the largest FDI amount among developing countries with a total amount of US\$854 million by 2008. It is unquestionable that this country has benefited enormously from FDI more than any countries worldwide. In 2010 alone, the total amount of FDI flowing into China stood at US\$ 105.7 billion, a remarkable rise from 2009's US\$ 90 billion ${ }^{143}$. As could be observed from Table 8, American cumulative FDI in China saw a constant increase from US\$ 11,140 million in 2000 to US\$ 60,425 million in 2010 (stock). Remarkably, the figure saw an increase of $22 \%$ in two consecutive years of 2009-2010. This, however, constituted only $1.7 \%$ of the total American FDI abroad $^{144}$. Overall, American FDI flows to this giant market remained extremely modest. Additionally, collected data from both Washington and Beijing showed that FDI from the US constituted only small part of the total FDI in China ${ }^{145}$.

Just as American firms collectively account for a relatively small component of FDI in China, American investment in China accounts for a relatively small portion of total US multinational activity around the world...total assets, sales and employment of US affiliates in China and in four regions that are the major destinations of US FDI. China's share of US MNE (multinational enterprise) total affiliate sales and assets were $1.9 \%$ and $0.7 \%$, respectively, in 2004 . Although the compound annual growth rate of US MNE sales in China over the 1982-2004 period exceeds 40\%, this rapid growth has proceeded from a small base, and it has taken place in a context of growing multinational activity worldwide ${ }^{146}$

\footnotetext{
${ }^{142}$ Lardy, Nicholas, R. 'China: The Great New Economic Challenge?' www.piie.com/publications/chapters_preview/3802/4iie3802.pdf (9 July 2013)

143 'Report to Congress of the US-China Economic and Security Review Commission' (2011), p. 50

144 'Report to Congress of the US-China Economic and Security Review Commission' (2011), p. 51

145 Branstetter, Lee and Foley, C. Fritz. 'Facts and Fallacies about US FDI in China'. National Bureau of Economic Research. Working Paper 13470, 2007, p.2

146 'Report to Congress of the US-China Economic and Security Review Commission' (2011), p. 3
} 
These collected data may not reflect the real picture of American FDI in China. Firstly, the statistics did not show up the re-investment amount from US companies. Secondly, collected data did not reflect the investment from unnamed investors through tax havens such as Hong Kong, British Virgin Islands and the Cayman Islands. Although these tax havens are in the top-ten list of investors to China, they are actually not the original source of the investment ${ }^{147}$. However, as data collected on an annual basis shows the otherwise, there are reasons to believe the assumption that US investment in China is large can be considered as one of fallacies in Sino-American economic relations ${ }^{148}$

\section{Chinese Investment in the US}

Beijing's investment in the US can be categorized into two groups: holding of US securities and FDI ${ }^{149}$. China's holding of US securities has been significant which totaled US\$ 1.7 trillion by June 2011 inclusive of US Treasury securities, US government agency security, corporate securities, and equities. In addition, the country overtook Japan to be the largest holder of American securities in 2009. More significantly, US treasury securities, which are used to finance budget deficit by the federal government, constitute the largest category of US securities held by China. China's holding of American treasury securities saw a massive increase in 2003-2010 period, both in terms of dollar and percentage of total foreign investment, and reached up to US\$ 14.3 trillion by the end of March, $2011^{150}$.

As shown at table 9, the total Chinese non-bond investment in the US was comparatively small. Beijing's cumulative FDI (stock) in Washington experienced a gradual increase from a small base of US\$ 503.32 million in 2003 to US\$ 4,873.99 million in 2010. According to the US Bureau of Economic Analysis, in 2009, China ranked as the $34^{\text {th }}$ largest FDI investor to the $\mathrm{US}^{151}$, a relatively low position given their bilateral enormous economic potentials. Several analysts insist that Beijing often uses tax havens to invest in other countries; therefore, the collected data did not reflect the overall

\footnotetext{
147 'Report to Congress of the US-China Economic and Security Review Commission' (2011), p. 51

${ }^{148}$ For additional information, see Branstetter, and Foley. 'Facts and Fallacies about US FDI in China'.

${ }^{149}$ Sutter. US-Chinese Relation: Perilous Past, Pragmatic Present p.199

${ }^{150}$ Morrison, Wayne, M. and Labonte, Marc. 'China's Holdings of US Securities: Implications for the US Economy’. Congressional Research Service 7-5700, RL 34314, 2012, pp.4-8.

151 'Report to Congress of the US-China Economic and Security Review Commission' (2011), p. 56
} 
picture of Chinese FDI flows to the $\mathrm{US}^{152}$. However, Chinese outward foreign investment, actually, "pales in comparison to inward investment" because "policies encouraging outward foreign investment are far more recent than those encouraging foreign investment in China" 153

In short, US investment in China and China investment in the US remain comparatively small given their huge economic potentials. The most prominent characteristic of Sino-American investment is, presumably, China's holding of US securities which shall also be discussed in detail in this research. More interestingly, the interdependence of the US and China quickly came to depend on investment flows, specifically China's holding of US securities, at least as much as trade flows, notably American large trade deficit with China. As noted earlier, these two characteristics lead these two great powers into the so-called "balance of financial terror" and make SinoAmerican economic interdependence a very important topic for discussion.

\section{RECENT SINO-AMERICAN TRADE DISPUTES}

The following section is devoted to discuss three trade issues emerging from economic interdependence between Washington and Beijing: American trade deficit, Chinese currency valuation and China's holdings of US treasury securities. In fact, their strong economic ties have created a great number of trade issues ${ }^{154}$, these three are chosen because of their relevance toward the arguments put forward by skeptics of the pacifying effects of economic interdependence on armed conflicts. Although these three issues have triggered considerable controversies, this section, however, attempts to provide a general picture of the issues. The controversial discussions over these frictions shall be discussed later on to provide better understanding of Sino-American economicssecurity nexus.

\section{Trade deficit}

China has run a trade surplus with the US which is clearly shown in data collected by both Beijing and Washington ${ }^{155}$. According to US statistics, Washington has incurred

\footnotetext{
152 'Report to Congress of the US-China Economic and Security Review Commission' (2011), p. 56

153 'Report to Congress of the US-China Economic and Security Review Commission' (2011), p. 55.

${ }^{154}$ For additional information, see Morrison, Wayne M. 'China-US Trade Issues'. Congressional Research Service ,2013, 7-5700, RL 33536 and Dumbaugh, Kerry. 'China-US Relations: Current Issues and Implications for US Policy’. Congressional Research Service, 2009, 7-5700, R40457

155 See Tables 1 to 7 .
} 
a trade deficit with China since 1983. According to Chinese figures, however, China has run a trade surplus with the US since 1993. In addition, with the exceptions of 1979 and 1980, there has been no consistency between two sets of figures recorded by the two countries. In 1983, for example, according to American data, Washington ran a trade deficit at US\$ 68 million. The figures were US\$22.8 million and US\$ 311 million in 1993 and 2012 respectively. Meanwhile, as collected by China, Beijing had a trade deficit at roughly US\$ 600 million in 1983 and a trade surplus at US\$ 6.28 million and US\$ 224.129 million with Washington in 1993 and 2012 respectively. More significantly, in 2006, China surpassed Japan to become a country having the largest trade surplus with the US, making itself the greatest challenge to America's economic superiority ${ }^{156}$. Specifically, "the deficit with China was the largest with any country or group of countries in an overall US trade deficit" ${ }^{\prime 157}$.

Although the actual size of the US-China trade deficit still remains unclear, China has been running an overall trade surplus with the US which has been growing over time with remarkably high speed and has caused considerable frictions between the two sides.

\section{Chinese Currency Valuation}

Criticism in the United States over China's currency policy emerged in recent years against the background of the massive and growing US trade deficit with China and complaints from US manufacturing firms and workers over competitive challenges posed by Chinese imports that benefit from the Chinese currency's value relative to the US dollar ${ }^{158}$

Specifically, China's decision to keep the value of its currency low with respect to the US dollar has emerged great concern among policy-makers, businesses and labor groups. China has fixed the yuan to the US dollar at a rate of $8.28 \mathrm{RMB}$ to the dollar from 1994 to $2004^{159}$. China has implemented the exchange rate reform by allowing its currency to "float within a specified range against a basket of currencies" since July $2005^{160}$. For China, its reform has increased the real effective exchange rate by roughly

\footnotetext{
${ }^{156}$ Liew, Leong. H. 'US Trade Deficits and Sino-US Relations', Department of International Business \& Asian Studies, Griffith University, Queensland, Australia, 2010., pp.4-8.

${ }^{157}$ Sutter. US-Chinese Relation: Perilous Past, Pragmatic Present, p.198.

${ }^{158}$ Sutter. US-Chinese Relation: Perilous Past, Pragmatic Present p.204.

${ }^{159}$ Dumbaugh. 'China-US Relations: Current Issues and Implications for US Policy', p.9

${ }^{160}$ Dumbaugh. 'China-US Relations: Current Issues and Implications for US Policy', p.9
} 
$30 \%$ and the rate "has reached a level of equilibrium"161. Given Chinese increasing reserves of foreign currency, for a Chinese government think tank, it is possible that the value of the yuan will continue to increase further in 2013. However, for Washington, the yuan remains significantly undervalued ${ }^{162}$, therefore, this issue remains a source of tension between the two sides.

\section{China's holding of US securities}

Chinese policy of maintaining its currency low with respective to the USD and other currencies has turned the country to the largest holder of foreign exchange reserves, especially the US dollar ${ }^{163}$. China's holding of US securities has been significant which totaled US\$ 1.7 trillion by June 2011 inclusive of US Treasury securities, US government agency security, corporate securities, and equities ${ }^{164}$. More significantly, US treasury securities, which are used to finance budget deficit by the federal government, constitute the largest category of US securities held by China ${ }^{165}$. "China's holding of treasury securities increased from $\$ 118$ billion in 2002 to nearly $\$ 1,161$ billion in 2010 , and its share of total foreign holding of US Treasury securities increased from $9.6 \%$ to $26.1 \%$, making China the largest foreign holder of US Treasury securities" ${ }^{\prime 66}$. In fact, a number of observers fear that China's holding of US securities provides this Asian giant with a big advantage over the American economy because China can manipulate American policies by threatening to sell its dollar reserves. This assumption has emerged one of the most serious trade disputes between Washington and Beijing.

\footnotetext{
${ }^{161}$ Zhao, Qian. 'US says yuan still undervalued'. Global Times, 2013.

162 Zhao, 'US says yuan still undervalued'

${ }^{163}$ Morrison, Wayne., M. and Labonte, Marc. 'China's Holding of US Securities: Implications for the US Economy'. Congressional Research Service RL34314, 2012, p.1

${ }^{164}$ Morrison and Labonte. 'China's Holding of US Securities: Implications for the US Economy', p.5

165 Morrison. 'China-US Trade Issues', p. 14.

${ }^{166}$ Morrison. 'China-US Trade Issues', p. 15.
} 


\section{CHAPTER 4 \\ THE RELEVANCE OF THEORIES TO SINO-AMERICAN ECONOMICS-SECURITY NEXUS}

This chapter addresses the research question: Can strong economic interdependence deter the two countries from entering armed conflicts against each other? Three propositions will be tested inclusive of trade increases conflict, trade decreases conflict and trade is irrelevant to conflict.

\section{PROPOSITION 1: TRADE INCREASES CONFLICT.}

Marxist-Leninist and neo-realist theorists have put forward two arguments to support the assumption that trade increases conflict. Firstly, they claim that the power from asymmetric interdependence may be used by the more powerful state to coerce or manipulate its trading partner. Since such extensive economic dependence poses challenges to the national autonomy, it can trigger efforts to break the dependent ties ${ }^{167}$. Secondly, states, in anarchy fear that the benefits of joint gains that advantage a trading partner might produce a more dangerous potential enemy. More importantly, while relative gains may not matter when state is engaged into business transactions with its allies or a relatively weak state, they do heighten considerable concerns when state is in a trading transaction with a relatively equal power or those who are potential to be an equal power. As a result, the gains from trade can be converted to security concerns. ${ }^{168}$

Are these two arguments applicable to Sino-American economics-security nexus? The first argument can be divided into two small parts: power from asymmetric interdependence and efforts to break dependent ties. To be more specific, two subquestions needs to be addressed: firstly, are the two countries engaged into a trade asymmetry; secondly, are there any efforts to break the dependency ties from Washington or Beijing? Furthermore, for the second argument, one single question needs to be answered: how much do relative gains matter to the US and China?

\footnotetext{
${ }^{167}$ Barbieri. 'Economic Interdependence: A Path to Peace or a Source of Interstate Conflict?', p.32

${ }^{168}$ Islam. 'The Post-Cold War US-China Relations: Win-Win or Zero-Sum Game', p.28.
} 
As perfect symmetry rarely exists, there is always the involvement of a potential power relationship in most cases of economic interdependence ${ }^{169}$. As discussed earlier, Washington and Beijing are trapped into the so-called "balance of financial terror", therefore, it needs more research and wide range of indicators to be ascertain which country is more powerful in this special economic relationship. This section, hence, shall examine only one part of the first argument. I find that there have been not yet any efforts to break the economic ties from both Washington and Beijing. Concerning the second argument, relative gains do matter and create some sources of frictions in Sino-American economic relationship, these frictions will not trigger into armed conflicts as long as trade is beneficial to both countries.

\section{Argument 1: Both countries do not want to break their economic ties}

In the 1980s, Washington became dependent on capital flows from Tokyo to maintain the balance in its federal government budget when President Reagan cut taxes and increased expenditure. Observers, at that time, worried that such dependence could provide Japan enormous power over the US. These observers, however, looked at only one side of the coin. Japan, at the same time, needed Washington for its continued growth. To be more specific, the US market was extremely crucial for Japan's exports. In other words, Washington and Tokyo engaged into strong economic interdependence and they both needed each other for further prosperity ${ }^{170}$.

Currently, a similar situation is applicable to Washington and Beijing because of the concerns over China's holding of US securities.

On one hand, US government leaders and other Americans encourage Chinese investment in such US securities as a means for the United States to meet its investment needs and to fund the large US federal budget deficit. One the other hand, US policy makers raise concerns that Chinese investment could give China increased leverage over the United States on major economic or other issues $^{171}$

China's holding of US securities, definitely, provides this Asian state a tremendous advantage over the US. Specifically, China can use its dollar reserves as a

\footnotetext{
169 Nye, Joseph, Samuel. Jr. 'American and Chinese Power after the Financial Crisis'. The Washington Quarterly. Vol. 33, No. 4, 2010, pp. 143-153, pp.146-9

${ }_{170}$ Nye 'American and Chinese Power after the Financial Crisis', p. 147.

${ }^{171}$ Sutter. US-Chinese Relation: Perilous Past, Pragmatic Present p.200
} 
weapon to manipulate US polices ${ }^{172}$. In addition, for several scholars, Chinese substantial dollar reserves can be considered as a great shift in the balance of power ${ }^{173}$ because "China could bring the US to its knees by threatening to sell its dollars" "174. However, the story is not so simple. Doing so, China would face two disasters: firstly, the value of its reserves would fall significantly; secondly, the US would possibly stop importing cheap Chinese goods leading to China's massive job loss and instability ${ }^{175}$ given that much of Chinese economy is still focused on exports despites recent attempts to stimulate domestic consumption in China itself ${ }^{176}$. In other words, "if it dumped its dollars, China would bring the US to its knees, but might also bring itself to its ankles" ${ }^{177}$. In short, Beijing needs a prosperous Washington for its continued growth. Instead of destroying American economy, China has to "invest in its (American) continued expansion" because it is "unable to disentangle its interests from those of the United States"178.

As the matter of fact, evidence has shown that neither Washington nor Beijing is willing to destroy the economic ties that lock them together. They are now in a situation which is similar to the military interdependence between the US and the Soviet Union during the Cold War in which each side had the potential to destroy the other but never $\operatorname{did}^{179}$.

In February 2010, angered over US arms sales to Taiwan, a group of senior military officers called for the Chinese government to sell off US government bonds in retaliation, but their suggestion was not heeded. Instead, Yi Gang, China's director of state administration of foreign exchange explained that "Chinese investments in US Treasuries are market investment behavior and we don't wish to politicize them. If they did, the pain would be mutual ${ }^{180}$

What can be observed from the story of China's holding of US securities? While China can use its dollar reserves as weapons to manipulate US policies, the country needs a prosperous America for its continued economic growth. In addition, the pain would be

\footnotetext{
${ }^{172}$ Beckley. 'China's Century? Why America's Edge Will Endure, p.47.

${ }^{173}$ An equilibrium of power between states

${ }^{174}$ Nye 'American and Chinese Power after the Financial Crisis', p.147

175 Nye 'American and Chinese Power after the Financial Crisis', p.148

${ }^{176}$ For additional information, see Yu, Yongding. China's Policy Responses to the Global Financial Crisis. 2009, Commonwealth of Australia.

${ }^{177}$ Nye 'American and Chinese Power after the Financial Crisis', p.148

${ }^{178}$ Beckley. 'China's Century? Why America's Edge Will Endure, pp.49-50.

${ }^{179}$ Nye 'American and Chinese Power after the Financial Crisis', p.148

${ }^{180}$ Nye 'American and Chinese Power after the Financial Crisis', p.148
} 
mutual for both countries if one tried to break the dependency ties. More importantly, both the two countries are not willing to destroy the economic ties that lock them together. Simply put, Sino-American strong economic ties create some sources of frictions while at the same time, deter these frictions to trigger into armed conflicts between the two sides.

\section{Argument 2: Concerns over Relative Gains Cannot Turn into a Sino-} American Armed Conflict

In this section, I will discuss the concerns over relative gains in Sino-American economic relations by looking at two stories of Chinese currency devaluation and American large trade deficit with China.

Firstly, the policy of a weak currency has aroused great concerns over Chinese relative gains in respect with America's. For critics, a weak yuan has produced great advantage for China by making its exports to Washington cheaper and American exports to Beijing more expensive than they would be if China maintained a market-based floating exchange rate. Additionally, a weak currency has seriously hurt American manufacturers (such as textiles, furniture, steel, etc) by making their products less competitive against Chinese low-cost imports ${ }^{181}$. More importantly, China's weak currency also adds "to the size and growth of the US trade deficit with China". ${ }^{182}$

Secondly, realist scholars have insisted that the massive trade deficit with China disadvantages the US. In recent years, although the trade deficit with China showed signs of decline as a result of US economic recession, the decline itself hardly puts an end to long-standing complaints by a great number of American Congressmen, media and interest groups ${ }^{183}$. Because of its huge deficit, the US needs to continue either borrowing from abroad or selling off capital assets to finance its consumption of goods and services. While continual borrowing from other countries is not a durable strategy, selling off capital assets can harm production. More importantly, jobs will be lost to overseas workers when imports exceed exports ${ }^{184}$. Chinese unfair and disadvantageous trade

\footnotetext{
${ }^{181}$ Sutter. US-Chinese Relation: Perilous Past, Pragmatic Present p.204.

${ }^{182}$ Sutter. US-Chinese Relation: Perilous Past, Pragmatic Present p.205.

${ }^{183}$ Sutter. US-Chinese Relation: Perilous Past, Pragmatic Present p.198.

184 "Trade Deficit: Good or Bad?"

http://www.infoplease.com/cig/economics/trade-deficits-bad-good.html (12 July 2013)
} 
policies have been blamed for this increasingly massive trade deficit ${ }^{185}$. Although the actual size of the US-China trade deficit still remains unclear, China has been running an overall trade surplus with the US which has been growing over time with remarkably high speed and has caused considerable frictions between the two sides.

The realist theory of relative gains is challenged by liberal notion of absolute gains. For liberal scholars, "pursuit of relative gain is misleading and destructive to the global economy and a hindrance to cooperation among states" ${ }^{\prime 86}$. In the next section, I will develop three arguments to prove that concerns over relative gains in Sino-American economic relationship are misleading and destructive.

Firstly, for the advocates of Chinese currency policy, a weak yuan is beneficial to American prosperity. Cheap Chinese imports lower "prices for US customers and dampens inflationary pressures" ${ }^{\prime 187}$. Moreover, a weak yuan allows American manufacturers to be more globally competitive because they can use imported Chinese inputs for their production ${ }^{188}$. In addition, critics of Chinese managed currency while overstates the role of a weak currency in surging China's exports ahead, ignores other factors such as low wage costs, highly skilled labor force and low cost of industrial finance $^{189}$. More importantly, as argued by Chinese officials, Chinese managed currency is meant for boosting domestic economic stability ${ }^{190}$.

In the medium to long terms...China is expected to continue to slowly appreciate its currency and loosen capital controls... The long-term pressure to appreciate the RMB is more likely to emanate from within China than from the United States or any other foreign power. This is in part because China's growing consumer class will demand more buying power to purchase both domestic and imported goods. And, perhaps more important, domestic firms will be less competitive abroad as prices within China rise without a commensurate appreciate in the RMB (the yuan) relative to foreign currencies. In addition, the gradual emergence of a large and more affluent middle class...could benefit the United States ${ }^{191}$

\footnotetext{
${ }^{185}$ Sutter. US-Chinese Relation: Perilous Past, Pragmatic Present p.198.

${ }^{186}$ Islam. 'The Post-Cold War US-China Relations: Win-Win or Zero-Sum Game', p.29.

${ }^{187}$ Sutter. US-Chinese Relation: Perilous Past, Pragmatic Present p. 205.

${ }^{188}$ Sutter. US-Chinese Relation: Perilous Past, Pragmatic Present p.205.

${ }^{189}$ Sengupta, Jayshree. 'Economic Relations between the US and Two Asian Giants, p.104

190 Swaine, Michael, D. 'America's Challenge: Engaging a Rising China in the Twenty-First Century' (Washington: Carnegie Endowment, 2011), p.205.

${ }^{191}$ Swaine. 'America's Challenge: Engaging a Rising China in the Twenty-First Century', p.214.
} 
Secondly, as discussed, the center of Asian regional production network has completely shifted to China since 2005, making the country the core market for immediate products and an assembling factory of the world. This feature makes the story of American massive trade deficit even more interesting one because the US saw an increase in trade deficit with China while experienced a decrease in trade deficit with other East Asian nations

East Asia's share of the US trade deficit actually declined from 1998 to 2007 (from 75 to 49 percent), as many East Asian nations shifted their exports toward China and their trade deficits with the United States decreased as a result ${ }^{192}$.

Again, other factors need to be taken into account when considering the US huge trade deficit with China. To start with, "most scholars argue that the competitiveness of US products and services are the crucial factors for reduction of trade deficit between the two countries" $" 193$. In addtition, the US government trade restrictions should be considered as another contributor to such a deficit. For example, in 2003, China imported a variety of high-technology products from the US inclusive of aircraft, nuclear reactors, machineries and equipments with a value of US\$ 10.6 million, accounting up to $40 \%$ of the US exports. This significant amount, however, only constituted $10 \%$ of China's total hightech imports. The US trade barriers, therefore, contributed to increase the problematic trade deficit for Washington ${ }^{194}$.

Thirdly, absolute gains ${ }^{195}$ in trade and economic relations should be considered in Sino-American economic relationship. It is undeniable that Washington has received enormous benefits from its trade with China. "Chinese goods helped US fight inflation because cheap imports held domestic prices down by offering competition and they also allowed Americans to enjoy a high consumption standard"196. Furthermore, American companies become more globally competitive because they choose China to assemble their products or use Chinese-made inputs for their productions ${ }^{197}$. More importantly, the US and Chinese economies are complementary to, rather than, competing with each other

\footnotetext{
192 Swaine, Michael, D. 'America's Challenge: Engaging a Rising China in the Twenty-First Century' (Washington: Carnegie Endowment, 2011), p.215.

${ }^{193}$ Islam. 'The Post-Cold War US-China Relations: Win-Win or Zero-Sum Game', p. 32

${ }^{194}$ Islam. 'The Post-Cold War US-China Relations: Win-Win or Zero-Sum Game', p.29.

195 The benefits being reaped by all parties involved.

${ }^{196}$ Sengupta. 'Economic Relations between the US and Two Asian Giants', p.104

${ }^{197}$ Morrison, W. M. (2011). China-US Trade Issues. Cornell University ILR School.
} 
because of their different cost structure and comparative advantages ${ }^{198}$. The US has comparative advantages in capital, technology and high quality human resources while those of China constitute its large population, unlimited low cost labor and abundance of natural resources ${ }^{199}$. The percentage of imports from China which compete directly with US-made products, according to a 1999 study, was not high, at only 10\%. In addition, Chinese products have replaced those from other low-wage countries such as East and Southeast Asia to America ${ }^{200}$. China has run a huge trade surplus with the US for a long time. Most of its exports, however, "are low value added labor intensive products and produced by multinational corporations and especially US multinational firms" ${ }^{201}$. Concerning its high-technology exports, it has not known yet how much China really gets from its export growth. To be more specific, the percentage of imported component for China's high-technology exports have increased over time, "a trend that suggests Chinese firms are falling further behind foreign competitors" ${ }^{202}$ and a considerable amount of the benefits from export-driven growth have been located outside China ${ }^{203}$.

Simply put, what can be observed from the stories of trade deficits and weak currency? Clearly, when it comes to trading relation between rivalries, especially between dyad of relatively equal powers, relative gains do matter and create some sources of serious security concerns. In the long run, however, there is no question that Sino-American trade relationship will benefit both countries. As long as their bilateral trade is beneficial to both sides, the concerns over relative gains cannot turn into an armed conflict between Washington and Beijing.

\section{PROPOSITION 2: TRADE DECREASES CONFLICT.}

As discussed in chapter 1, economic interdependence, as described by liberal theorists, lowers the possibility of war by increasing the value of trade over the alternative of aggression and making wars costly between states, especially those with a high level of economic interdependence. Conflict between trading partners, therefore, is less likely to occur between pairs of states that do not trade. More remarkably, partners

\footnotetext{
${ }^{198}$ Islam. 'The Post-Cold War US-China Relations: Win-Win or Zero-Sum Game', p.29.

${ }^{199}$ Islam. 'The Post-Cold War US-China Relations: Win-Win or Zero-Sum Game', p.29.

${ }^{200}$ Islam. 'The Post-Cold War US-China Relations: Win-Win or Zero-Sum Game', p.29.

${ }^{201}$ Islam. 'The Post-Cold War US-China Relations: Win-Win or Zero-Sum Game', p.29.

${ }^{202}$ Beckley. 'China's Century? Why America's Edge Will Endure, p.68

${ }^{203}$ Breslin, Shaun. 'China and the Crisis: Global Power, Domestic Caution and Local Initiative' Contemporary Politics, Vol. 17, No.2, 2011, pp. 185-200, p.187
} 
who have an increasing amount of trade volume should be more concerned with avoiding conflict, in comparison with those which are not increasing their trading activities ${ }^{204}$. I found out that although high level of economic interdependence does help dampen any tendencies toward an armed conflict, strong economic ties are not sufficient enough to create lasting stability between Washington and Beijing. The next section, therefore, is in two parts. The first part is devoted to the examination of how relevant the five arguments of advocates are to the Sino-American economics-security nexus. The second part presents grounds for skepticism or flaws of these arguments.

1. The relevance of five liberalist arguments to Sino-American economicssecurity nexus

\subsection{Argument 1: Trade decreases conflict because it is beneficial to all trading} states

Firstly, liberalist theorists assume that states participates in trading activities voluntarily because trade benefits them all. States, for liberalist scholars, obtain benefits through exchanges and greater specification, therefore, become richer. Specifically, through trade, states exchange products by selling and buying things with cheaper prices, thus, gain revenue and boost consumption ${ }^{205}$. Furthermore, trade also helps states to specialize in goods and services which they hold comparative advantages ${ }^{206}$, therefore, increase states' economic efficiency. Due to the gains from trade, states shall avoid any possibility of conflict.

This argument is applicable to Sino-American conflict. As discussed, the two countries have enjoyed tremendous benefits from trading with each other. In addition, the two economies are complementary to, rather than competing with each other. While the US has advantages in capital, technology and high quality human resources, China has a large population, unlimited low cost labor and abundance of natural resource ${ }^{207}$. Moreover, China specializes in low value added labor intensive products and this

\footnotetext{
${ }^{204}$ Rapkin, David, P. and Thompson, William, R. 'Will Economic Interdependence Encourage China's and India's Peaceful Ascent? Strategic Asia 2006-7, p.343

${ }^{205}$ Barbieri, Katherine. 'The Liberal Illusion: Does Trade Promote Conflict'. (The University of Michigan Press, 2005), p.23

${ }^{206}$ The ability to produce goods and/or services at a lower opportunity cost than other's

${ }^{207}$ Islam. 'The Post-Cold War US-China Relations: Win-Win or Zero-Sum Game, Asian Affairs, p.29.
} 
specialization has increased since $1995^{208}$, therefore, imports from China can hardly compete with American made high-value added products ${ }^{209}$. In short, as trade is mutually beneficial to both Washington and Beijing, the two sides undoubtedly shall avoid conflict and secure peaceful environment to prosper their economic relationship.

\subsection{Argument 2: Trade decreases conflict because there is a strong desire to} avoid conflict from the sub-systemic/domestic level

Secondly, another argument supporting the conflict-suppressing of economic interdependence explains the proposition "trade promotes conflict" at domestic level. Accordingly, the greater the volume of trade and investment flowing between two countries, the more people on both sides should have a strong desire to avoid conflict. This argument is true to Sino-American relationship. In fact, these two largest economies are connected so tightly that they are known as a single organism of "Chimerica" Chimerica makes up only $13 \%$ of the world in terms of size, "but a quarter of its population and fully a third its GDP",211.

Given the massive gains from trade as well as the prospects of more benefits in the future, it is no surprise to see governments of both Washington and Beijing are currently under great pressure to secure mutual peace by different actors who benefit enormously from trade. For the political and business elite, a stable and cooperative SinoAmerican relationship is crucial for the national prosperity of both sides and their personal well-being ${ }^{212}$.

China is currently the United States' second largest trading partner, its third largest export market, and its biggest source of imports. According to one estimate, China is currently a 250 billion USD market for US firms...China's large population and booming economy have made it a large and growing market for US exporters and investors. Many US firms view participation in China's market as critical to staying globally competitive ${ }^{213}$.

\footnotetext{
${ }^{208}$ World Trade Organization, 'Trade Patterns and Global Value Chains in East Asia: From Trade in Goods to Trade in Tasks', p.70

${ }^{209}$ Islam. 'The Post-Cold War US-China Relations: Win-Win or Zero-Sum Game, Asian Affairs, p.29.

${ }^{210}$ China and America.

${ }^{211}$ Ferguson, Niall and Schularick, Moritz. 'Chimerica and the Global Asset Market Boom'. International Finance, Vol. 10, No.3, 2007, pp.215-239, p.228

${ }^{212}$ Friedberg, Aaron, L. 'A Contest for Supremacy: China, America, and the Struggle for Mastery in Asia'. Roots of Rivalry (New York: W. W. Norton \& Company, 2011), pp. 36-58, p.46

${ }^{213}$ Morrison. 'China-US Trade Issues'. Congressional Research Service, Summary.
} 
More importantly, thanks to trade, many Americans, notably American business interest groups, see China's rise as opportunities not only dangers ${ }^{214}$. Meanwhile, if not for trade, 'some in China would feel even more threatened by America's preponderance" 215 . This argument, thus, is clearly obvious and "at least for the moment, leading figures in both countries do not appear to need much convincing on these points" ${ }^{216}$.

\subsection{Argument 3: Trade decreases conflict because it is a more efficient mean} for creating wealth and influence

Thirdly, another argument attributing the inverse relationship between trade and conflict is that trade now plays an increasingly more efficient means for creating wealth and influence than the old method of military conquest and external expansion. In this section, I will point out three reasons to explain why this argument is relevant to SinoAmerican relationship.

To begin with, recent trends have offered strong evidence that war has almost ceased to exist ${ }^{217}$. More importantly, there has seen fewer and less deadly international conflicts $^{218}$. In addition, the incentives for aggression to gain economic benefits from conquered territories have actually decreased over time. The most reasonable explanation for this decrease is due to the recent shift in "the most modern countries from economies based on land to ones primarily based on human capital" 219 or knowledge-based economies $^{220}$. While America has successfully transformed toward a knowledge-based economy, China encountered a number of great difficulties and has not yet achieved relevant economic and social foundation for such an economy due to, presumably, its weakness in high-tech innovation ${ }^{221}$. However, Beijing has obtained enormous benefits

\footnotetext{
${ }^{214}$ Friedberg. A Contest for Supremacy: China, America, and the Struggle for Mastery in Asia, p. 46

${ }^{215}$ Friedberg. A Contest for Supremacy: China, America, and the Struggle for Mastery in Asia, p. 46

${ }^{216}$ Friedberg. A Contest for Supremacy: China, America, and the Struggle for Mastery in Asia, p. 46

${ }^{217}$ For additional information, see Mueller, John. 'War Has Almost Ceased to Exist: An Assessment'. Political Science Quarterly, Vol. 124, No. 2, 2009, pp. 297-321.

${ }^{218}$ For additional information, see Human Security Report 2009-10. Why International Wars Are Increasingly Rare, pp. 21-35.

${ }^{219}$ Brooks, Stephen, G. 'The Globalization of Production and the Changing Benefits of Conquest'. Journal of Conflict Resolution, Vol. 43, No. 5,1999, pp.646-670, p. 655.

${ }^{220}$ Detailed discussion on reasons why shift to knowledge-based could lower benefits of conquest could be found in Brooks. 'The Globalization of Production and the Changing Benefits of Conquest'.

${ }^{221}$ For additional information, see Zhongqing, Tian. The knowledge-based economy in China: perceptions and facts. Retrieved from: epress.anu.edu.au/wp-content/uploads/2013/05/ch076.pdf
} 
from the current international order and governance. The country would find ways to satisfy its growing weight, values and interests but not a revolutionary states trying to overthrow the current international system ${ }^{222}$. Finally, as discussed, trade provides both Washington and Beijing great benefits, therefore, makes the two countries, especially China, richer proving it an efficient mean for creating influence.

China's wealth changes America's relationship with it because the old saying is right: ultimately, wealth is power. America itself has shown this to be true, with its global power built on its economic preponderance. Now China's swift economic rise is driving a rapid shift in relative strategic and political power ${ }^{223}$.

\subsection{Argument 4: Trade decreases conflict because the lost benefits associated} with trade interruption are taken into leaders' calculation

Fourthly, those who insist that economic interdependence deters intense form of conflict when leaders consider the lost benefits associated with trade interruption. In other words, it is not trading activities but fear of losing economic benefits that prevent states from starting wars against their major trading partners ${ }^{224}$.

At the first glance, this argument is true to Washington and Beijing. An interruption to trade between these two Pacific nations would be unimaginable. Undoubtedly, Sino-American trade interruption would drown hundreds of foreign traderelated industries, increase bad debts, leave tens of thousands of American unemployed in a short time, force tens of thousands of Chinese migrant worker to return home, drop household consumption substantially, and escalate American debt crisis rapidly ${ }^{225}$. Given the tremendous benefits from their economic relationship and damaging consequences in case of trade termination between the two, it is undeniable that leaders of both sides would be very much affected by concerns over the future economic loss in case of armed conflict. The most outstanding example could be American concerns over a rising China which poses challenges to American dominance in the world. However, it is even hard

\footnotetext{
${ }^{222}$ Muthiad, Alagappa. 'A Changing Asia: Prospects for War, Peace, Cooperation, and Order' Political Science, Vol. 63, No. 2, 2011, pp. 155:185, p. 175.

${ }^{223}$ White, Huge. 'The China Choice: Why America Should Share Power'. A Hard Choice. (Collingwood: Black Inc., 2012), p.3

${ }^{224}$ Barbieri. 'The Liberal Illusion: Does Trade Promote Conflict', p.23

225 Wang, Jianhua and Li Yunlu. 'China-US Trade War No Good for Anyone'. People's Daily Online, 2011

http://english.peopledaily.com.cn/90780/7616581.html (13 August 2012)
} 
for Washington to apply containment ${ }^{226}$, a successful policy against the Soviet Union, to China because of the massive economic interdependence between the two $\operatorname{sides}^{227}$, not mentioned a war. For Beijing, it has made considerable efforts to minimize the impact of national uprisings to maintain stable Sino-US relations in case of US bombing of its embassy in Belgrade in 1999 and the reconnaissance plane incident in 2001228.

In short, Washington "welcomes the continuing peaceful rise of China as a world power and that, in fact, it is in the United States' interest that China continues on the path of success, because we (the US) believe that a peaceful and stable and prosperous China is not only good for Chinese but also good for the world and for the United States" 229 . Meanwhile, for China, the two countries "have vast convergence of shared interests, from promoting our respective economic growth at home to ensuring the stability of the global economy; from addressing international and regional hotspot issues to dealing with all kinds of global challenges. On all these issues, our two countries need to increase exchanges and cooperation" 230 .

\subsection{Argument 5: Trade decreases conflict because there are a convergence of} national interest and spill-over effects ${ }^{231}$.

Finally, economic interdependence is assumed to be linked and intertwined with economic and political structures of states which results in the convergence of national interests. Specifically, the stronger and closer commercial linkages among states are, the more cooperative they will be in other areas. As a result, there shall emerge a number of institutions, both formal and informal to foster trade and have spillover effects in other fields.

At the first glance, this argument seems fit the Sino-American relationship. There is a convergence of national interests between Washington and Beijing, which is to maintain a strong economic relationship with each other. Both sides have strong

\footnotetext{
${ }^{226}$ The action or policy of preventing the expansion of a hostile country or influence

${ }^{227}$ White, Huge (2012). America's China Dilemma. Straits Times.

${ }^{228}$ For additional information, see Tung, Chen-Yuan 'The Impact of Bilateral Economic Interdependence on US-China Relations'.

http://www3.nccu.edu.tw/ ctung/Documents/W-B-a-7.doc (13 July 2013)

229 'Obama, Xi Emphasize Importance of U.S.-China Relationship'. US Department of Defense, 2013. http://www.defense.gov/news/newsarticle.aspx?id=120242 (13 July 2013)

230 'Obama, Xi Emphasize Importance of U.S.-China Relationship'

${ }^{231}$ The notion that integration between states in one economic sector will create strong incentives for integration in further sectors
} 
motivation for expanding its economic ties with each other because trade has provided Washington tremendous benefits and also brought prosperity and technical advancement to China ${ }^{232}$. Additionally, it is undeniable that both sides would be badly affected if the US intentionally hampered the economic development of China ${ }^{233}$.

A prosperous China is crucial for a wealthy America. However, it is wealth and technical advancement which have enhanced Chinese military capability. And there is no doubt that China will continue to spend more on defense unless its economy collapses. Meanwhile, a weak economy would limit Washington's capability to increase its military budget and ease the strategic pressure on China. However, it would also hamper the economic development of Beijing because China still needs to be able to sell its goods to the United States to remain afloat. The two countries, therefore, are trapped in both positive and negative factors which are closely interwoven and often run into one another ${ }^{234}$.

Furthermore, strong Sino-American economic interactions have also resulted in further cooperation in other fields. In reality, Washington and Beijing are not only bound together by the discussed commercial ties but also by cultural, societal and scientific linkages $^{235}$. For example, the number of Chinese students studying in the US soared from roughly 1,000 in $1979-80$ to more than 60,000 in 2002. Meanwhile, the figures of American students studying in China increased remarkably from zero to roughly 5,000 during the same period ${ }^{236}$. More remarkably, he population of Chinese students in the US keeps growing and constitutes up to $25 \%$ of all international students in the United States in the school year of 2011-2012 237 . In addition, child adoption is another example of close social connections with over 5,000 Chinese children adopted by American families

\footnotetext{
${ }^{232}$ Wang, Jisi. 'China' Search for Stability with America'. Foreign Affairs. Vol.84, No.5, Sep.-Oct. 2005, pp.39-48, p.47

${ }^{233}$ Wang. 'China' Search for Stability with America'. Foreign Affairs, p.47

${ }^{234}$ Wang. 'China's Search for Stability with America', p.47

${ }^{235}$ Shambaugh, David. 'Facing Reality in China Policy'. Foreign Affairs, Vol.80, No. 1 (Jan-Feb, 2001), pp.50-64, pp.55-6

${ }^{236}$ Zhiqun, Zhu. 'Power Transition and US-China Relations: Is War Inevitable?' Journal of International and Area Studies, Vol. 12, No, 1, 2005, pp. 1-24, p.13

${ }^{237}$ Hopkins, Katy (2012). 'International Students Continue to Flock to US Colleges, Grad Schools'. US News. $\quad$ http://www.usnews.com/education/best-colleges/articles/2012/11/12/international-studentscontinue-to-flock-to-us-colleges-grad-schools (18 July 2013)
} 
in 2000 alone $^{238}$. Also, steady currents of scientists and other professionals for research collaboration, professional meetings, view sharing and frequent exchanges of culture and athletes, sister-cities, etc have greatly contributed to strengthen the social and cultural linkages $^{239}$. Moreover, Washington and Beijing has also furthered their cooperation in dealing with non-traditional securities issues such as terrorism, energy security and climate change ${ }^{240}$.

Simply put, the examination of the five liberalist arguments to Sino-American relationship has shown that all arguments, to some extent, fit the case studies. In fact, it is undeniable that a high level of economic interdependence has bound these two Pacific nations together and helped to create a relative peaceful environment for Washington and Beijing to prosper. However, there are grounds for skepticism. Firstly, governments are not, as a matter of fact, always deterred by the prospect of future economic loss. Secondly, it is not yet certain that mutual linkages of all kinds can damper intense forms of conflict. Thirdly, as discussed in proposition 2, economic interdependence can be a source of frictions. The following section is devoted to discuss all these three points.

\section{Grounds for skepticism}

There is no doubt that the remarkably strong economic interaction have served as one of the most important factors contributing to the relative stability between Washington and Beijing for the last several decades. However, high levels of economic interdependence cannot explain many recent incidents of China pushing back against the US. The following section is, therefore, devoted to discuss three grounds for skepticism.

\subsection{Argument 1: Leaders are not always deterred by the prospects of economic} loss

Firstly, government, unfortunately, are not always deterred by the future economic loss. Since leaders usually assume, mistakenly, that the effect of their decisions will be short and minimally disruptive, they often underestimate the cost of their actions. For some particular situations, even if leaders know for sure that their decisions will seriously damage the material well-being of the most powerful interest groups or even an

\footnotetext{
${ }^{238}$ Zhiqun. 'Power Transition and US-China Relations: Is War Inevitable?', p.14.

${ }^{239}$ Shambaugh. 'Facing Reality in China Policy', pp.55-6

${ }^{240}$ For additional information, see Zhang, Jiadong and Zheng, Xin. 'The Role of Nontraditional Security in China-US Relations: Common Ground or Contradictory Arena'. Journal of Contemporary China, Vol. 21, No. 76, 2012, pp.623-636.
} 
entire nation; they still put security concerns over economic ones. The most outstanding example can be found in China-Taiwan relationship ${ }^{241}$. "China is bound even more tightly by economic ties to Taiwan than it is to the US. Yet few observers doubt that Beijing would use force to prevent moves toward independence, despite enormous direct costs of doing so, to say nothing of the possibility of economic sanctions, limited conventional conflict, and perhaps even a nuclear exchange with the United States". 242

\subsection{Argument 2: Linkages cannot guarantee peace}

Secondly, the presences of common interests and close linkages in different fields certainly have their own roles in damper any tendencies toward an armed conflict.

The United States and China have developed a normal relationship, in which they cooperate on a wide range of bilateral, regional and global issues....US-China ties have strengthened and expanded...General speaking, common grounds and common interests far outweigh disputes and disagreements between the United States and China ${ }^{243}$.

However, it is not yet certain that such linkages afford the guarantee that war can be avoided. We then come back to the triangle relationship of the US, China and Taiwan. The mutual strong ties of culture, society, science and even commerce certainly cannot guarantee a Sino-American peaceful relationship if Washington were back Taiwanese independence ${ }^{244}$.

\subsection{Argument 3: There is historical evidence that economic interdependence}

\section{could not prevent war}

Finally, as discussed in the previous scenario, economic interdependence can be a cause of insecurity and friction. What brought Washington and Beijing together in early 1970 was not economic interdependence, but rather the convergence of national interests emerged from the common threat of the Soviet Union. Since the demise of the Soviet Union in early 1990s, economic interdependence while binds the two countries together, becomes a major source of insecurity between the two sides. The discussed trade deficit, currency valuation and China's holding of US securities are outstanding example of how interdependence can trigger great disagreements between Washington and Beijing. However, these differences, as noted earlier, are not strong enough to trigger an armed

\footnotetext{
${ }^{241}$ Friedberg. 'A Contest for Supremacy: China, America, and the Struggle for Mastery in Asia', p.47

${ }^{242}$ Friedberg. ' A Contest for Supremacy: China, America, and the Struggle for Mastery in Asia', p.47

${ }^{243}$ Zhiqun. 'Power Transition and US-China Relations: Is War Inevitalbe?', p. 17

${ }^{244}$ Friedberg. 'A Contest for Supremacy: China, America and the Struggle for Mastery in Asia.
} 
conflict between the two sides. These discussions drive us to the last proposition: Trade is irrelevant to conflict.

\section{PROPOSITION 3: ECONOMIC INTERDEPENDENCE IS}

\section{IRRELEVANT TO CONFLICT.}

The third scenario is based on the offensive realist assumption that the causes of war are based on political and military-strategic considerations rather than being either advanced or hindered by purely economic ones. Specifically, trade may serve as a mean to pursue the national interests which can easily be broken when states consider military conflict options. I find that this proposition perfectly fits the complex Sino-American economics-security relationship. This finding is based on three arguments concerning the usage of trade, historical evidence and the existence of other factors which help to bind the two countries together.

\section{Argument 1: Trade is meant for other purposes}

Firstly, Washington is not heavily dependent on the global economy for its prosperity and influence because "exports and imports both represent a smaller percentage of US gross domestic products than is the case in every other major economy and most minor ones" ${ }^{245}$. The US dependency on the global market was mainly reflected by its public debt "which because of unparalleled US power and the reserve currency role of the dollar has permitted the US to accumulate so much external debt for so long that the country is at-if not already beyond-the boundaries of prudent economic behavior"246. The US extraordinary indebtedness reflects the American ability to make use of a peculiar benefit of interdependence arising from the fact that foreign governments which hold dollar reserves have no choice but to rely on US prosperity for their continued economic growth ${ }^{247}$.

In such circumstances (creditors of the US have no choice but to finance the continuing US trade deficits), the US dependence on trade, which is relatively modest to begin with, could have even less of political restraining effect than might otherwise be case, which is arguably good news for

\footnotetext{
${ }^{245}$ Tellis, Ashley, J. 'Trade, Interdependence and Security' in Tellis, Ashley, J and Wills, Michael (ed.). Trade, Interdependence and Security in Asia. (Washington: The National Bureau of Asian Research, 2006) pp.1-25, p. 10.

${ }^{246}$ Tellis. 'Trade, Interdependence and Security', p.10

${ }^{247}$ Tellis. 'Trade, Interdependence and Security', p. 11
} 
the pursuit of US strategic objectives in Asia, especially when these embody some risk of conflict with a country such as China ${ }^{248}$.

On contrary, official figures suggested that China's export increased from $20 \%$ of GDP in 2001 to roughly $40 \%$ in 2007 . For some scholars, this "roughly $40 \%$ of GDP" still underestimates the role of exports in Chinese economy, believing the figure can go up to $50 \%^{249}$. Simply put, this export-orientation growth can be seen as one of the most important characteristics of China's growth pattern which has driven the country to a high level of dependence on the global economy for achieving high economic growth rate.

More importantly, "export-led growth then becomes the instrumentality that enables Beijing to keep the United States invested in strong economic links with China, thereby hopefully dissuading Washington from constraining China's rise" ${ }^{250}$. At the same time, the economic miracle of China has created a web of interdependence that ties the prosperity of China to both its rivals and friends. Therefore, for China, trade is meant for two purposes. Firstly, trade is the fastest mean to increase its national wealth "which in turn provides the state (China) with the resources required both to maintain the social contract that preserves the state's power and to secure those capabilities deemed necessary to protect national interests" ${ }^{, 251}$. Secondly, trade also provides a strategic instrument which can bind China and its rivals including the US "while concurrently limiting the freedom of action of China's regional neighbors, who presumably would be

\footnotetext{
${ }^{248}$ Tellis. 'Trade, Interdependence and Security', p. 11

${ }^{249}$ Breslin. 'China and Global Crisis: Global Power, Domestic Caution and Local Initiative', p.188

${ }^{250}$ Tellis. 'Trade, Interdependence and Security', p. 11

${ }^{251}$ Tellis. 'Trade, Interdependence and Security', pp. 11-12
} 
unwilling to bandwagon with countries that might imperil the source of their current prosperity"252.

In short, these in-depth analyses have shown that, for China and the US, trade is not used to suppress conflict but to maximize their national power. The behaviors of both Washington and Beijing have reflected their profound understanding of the economic and international political lessons ${ }^{253}$.

They (including the US and China) appreciate that robust economic growth alone enables them to protect their states in the manner they deem desirable, that trade enables these states to expand their national power faster in comparison to alternative national strategies, and that the growth in power, which derives from both trade and internal resource mobilization, enables them to ward off threats and manage risks while strengthening their ability to secure whatever strategic goals they may happen to pursue ${ }^{254}$.

\section{Argument 2: There are a great number of factors building up the Sino-}

\section{American peace}

Secondly, looking back at history, there is little evidence to believe that economic interdependence alone can bring lasting stability in the international order. For instance, Britain and Germany were major trading partners before the First World War. Strong economic linkages between the two sides and the prospects of economic loss, however, failed to deter Britain's leaders from seeing a rising Germany as a challenge to their colonial empire $^{255}$. Meanwhile, it also failed to prevent Germany from "concluding that Britain was intent on retaining its preponderant position and blocking Germany's rise" 256. In other words, the prospects of future massive economic loss did not stop the two countries from entering in one of the most disastrous wars in human history.

Of course, we have not observed any dyad of major powers which have such a high level of mutually dependence as it has been in the case of Sino-American economic relationship ${ }^{257}$. The economic loss from a war between Washington and Beijing would be definitely much more disastrous than it was in the case of Germany and Britain, not to

\footnotetext{
252 Tellis. 'Trade, Interdependence and Security', p.12

253 Tellis. 'Trade, Interdependence and Security', p. 25

${ }^{254}$ Tellis. 'Trade, Interdependence and Security'. p. 25

${ }^{255}$ Friedberg. A Contest for Supremacy: China, America, and Struggle for Mastery in Asia, p.47

${ }^{256}$ Friedberg. A Contest for Supremacy: China, America, and Struggle for Mastery in Asia., p.47

${ }^{257}$ Barbieri. The Liberal Illusion: Does Trade Promote Peace?, p.117
} 
mention the fact that they belong to the nuclear club. However, given the discussion above, we know for sure that a high level of economic interdependence alone cannot deter the two countries from intense form of conflict. As it was in the case of Britain and Germany, "an assortment of factors-including bilateral economic relations; shifts in the global distribution of power; developments in military technology; domestic political processes; ideological trends; questions of radical, religious, cultural, and national identity; the actions of key individuals; and the sequencing of critical events-combined to lead Britain and Germany to the brink of World War I" ${ }^{258}$. The question of whether or not the history will repeat itself in the case of Washington and Beijing, therefore, cannot be limited only to the discussion on the impact of economic interdependence on interstate relationship.

It is incorrect if one too quickly concludes that strong economic ties do not help to dampen tendencies toward conflict. In fact, if not for trade, Washington and Beijing could not have been as close as they were today. However, as discussed earlier, economic interdependence alone is not sufficient to create lasting stability between these two most powerful nations. What are the other factors which bring Washington and China to a relatively stable relationship? There are, in fact, a number of factors such as the emergence of common non-traditional threats, the mutual possession of nuclear weapons, international institutions, democratization, etc which have contributed to the relatively stable Sino-American relationship for the last several decades ${ }^{259}$.

\footnotetext{
${ }^{258}$ Friedberg. 'The Future of US-China Relations: Is Conflict Inevitable?', p.12.

${ }^{259}$ For additional information, see Friedberg. A Contest for Supremacy: China, America, and Struggle for Mastery in Asia and Friedberg, 'The Future of US-China Relations: Is Conflict Inevitable?'
} 


\section{CHAPTER 5}

\section{CONCLUSION AND POLICY IMPLICATIONS}

In international relations, economic interdependence has two basic meanings. Firstly, a group of countries is considered to be economically interdependent if changes in one economy can seriously affect the others. Secondly, countries are considered to be economically interdependent if it would be costly for them to terminate their trading relationship. While the former corresponds to sensitivity interdependence, the later corresponds to vulnerability interdependence. The differences of these two dimensions of interdependence have been well noticed by scholars of international relations and even economists. However, given its nature of obscurity and confusedness, sensitivity should be retained but needs to change its label to something less misleading. Therefore, interdependence should be corresponded with its clear, time-honored and still useful dimension of vulnerability, defined as the opportunity costs of interrupting a trading relationship.

This definition of economic interdependence fits the Sino-American relationship. We have not seen any two major powers which have such strong economic ties in history. And it is undeniable that it would be too costly for both Washington and Beijing in case of trade interruption.

In this research, indicators of trade and investment have been used to measure Sino-American economic interdependence. In terms of bilateral trade, Washington and Beijing have observed increasing business transactions since the two countries normalized their diplomatic relations in 1979. The most prominent feature of the trade relationship between these two Pacific nations is a steadily growing trade imbalance. China currently constitutes American largest bilateral trade deficit. In terms of bilateral investment, the collected data is comparatively small given their huge economic potentials. However, the interdependence of America and China quickly become to depend on investment flows at least as much as trade flows because of China is now the biggest holder of US securities. Simply put, economic factors have assumed a weight that both sides could no longer discount. China is vital to American economic health. There is no doubt that American prosperity greatly depends on decisions made in Beijing. Also, 
China needs the American market to remain afloat. In addition, China needs a strong US economy because the slowdown in Washington can severely affects China development. These two Pacific nations are trapped into the so-called balance of financial terror because America is Chinese largest export market and China is American largest creditor. It is no doubt that economic factors have greatly contributed to a relatively peaceful and cooperative Sino-American relationship.

Three propositions have emerged from disputes over the vices and virtues of economic interdependence on interstate relationship. All these three propositions are examined in this research in order to address the research question: Can a high level of economic interdependence serve as a deterrent to Sino-American armed conflict?

Firstly, an examination of the first proposition of "economic interdependence increases conflict" has shown that the strong economic interaction has actually caused tensions between the two Pacific nations. Trade issues of American's large deficit with China, Chinese currency devaluation and China's holding of American securities are among major issues. However, these issues of great disputes are not strong enough to turn into war between Washington and Beijing because both countries are not willing to destroy the economic ties that lock them together. If they did, the pain would be too costly for both. Also, as long as trade is beneficial to both sides, concerns over relative gains cannot trigger into war between the two sides.

Secondly, the proposition of "economic interdependence decreases conflict" is also not relevant to the Sino-American relationship. Five arguments have been proposed by liberalist theories to support the pacifying effect of trade. In fact, it is undeniable that economic interdependence has greatly enhanced a relatively peaceful and cooperative Sino-American relationship. In fact, if it were not because of a high level of interdependence, the two countries would not be as close as they are today. However, there are grounds for skepticism. First, leaders always put the security concerns over the prospects for economic loss, especially in times of insecurity and vulnerability. Second, the convergence of national interests and different linkages between Washington and Beijing have their own roles in leading both sides to a stable relation but it is not yet certain that such linkages afford the guarantee that war can be avoided. Thirdly, SinoAmerican interdependence is different from those in the past. However, we are not sure 
about their future because there is little evidence to believe that economic interdependence alone can bring lasting stability in the international order.

Thirdly, the third proposition "economic interdependence is irrelevant to conflict" perfectly fits the Sino-American relationship. There are two strong supporting points for my conclusion. First, trade is not meant to suppress conflict but to maximize national power for both Washington and Beijing. Second, the question of whether or not the two countries will engage into a war against each other should not be limited only to the discussion on economic interdependence. In other words, economic factors alone cannot deter an armed conflict between Washington and Beijing. Furthermore, both sides have kept their relationship relatively stable during the last several decades not only because of their strong economic ties but also other factors such as: the emergence of common nontraditional threats and the mutual possession of nuclear weapons.

This research suggests that the conflict-suppressing impact of economic interdependence on Sino-American relationship has been exaggerated. Strong economic ties contribute to the stability of the relationship between Washington and Beijing but cannot guarantee it.

Then a question should be addressed: What does a high level of economic interdependence mean for Washington and Beijing? Given its high level of economic interdependence, what should Washington and Beijing do?

Firstly, both Washington and Beijing should not cling to the hope that trade can promote peace but need to study the nature and context of economic linkages carefully ${ }^{260}$. As long as they understand the factors which can deter intense form of conflict in trading relations, they "will be better equipped to assess the potential impact of interdependence and to identify those relationship that are most likely to maximize the benefits of economic relationships, while minimizing the costs of economic relationship" 261

Secondly, due to the changing structure of the global economy, nowadays, the most powerful nations can hardly obtain the gains from trade as they used to be. The concerns over the relative gains, therefore, can hamper cooperation between Washington and Beijing because it is not about the total gain available but how the gains are shared.

\footnotetext{
${ }^{260}$ Barbieri. The Liberal Illusion: Does Trade Promote Peace?, p. 126

${ }^{261}$ Barbieri. The Liberal Illusion: Does Trade Promote Peace?, p. 126
} 
As the matter of fact, "tensions over economic issues may increase as stakes of economic policies become more critical" 262 . In the past, since the economic expansion allowed state to enjoy greatly from trade, the concerns over relative gains might not be serious as it is today. The global economic crisis may seriously heighten the concerns over relative gains because of the assumption that now the economic pie is much smaller ${ }^{263}$. Therefore, countries should understand the impact of increased interdependence and design policies "to minimize the costs associated with interdependence, while also maximize its benefits. They must also consider the overall context in which trading relationships are embedded in evaluating whether it is desirable to expand dependence on any given state" 264 .

\section{AFFIXES}

Table 1265: Sino-American Trade, 1971-1980 (American Figures)

\begin{tabular}{|l|l|l|l|l|l|l|}
\hline Year & $\begin{array}{l}\text { US Imports } \\
\text { from PRC }\end{array}$ & $\begin{array}{l}\text { US Exports } \\
\text { to PRC }\end{array}$ & $\begin{array}{l}\text { Total } \\
\text { Bilateral } \\
\text { Trade }\end{array}$ & $\begin{array}{l}\text { US Trade } \\
\text { Balance }\end{array}$ & $\begin{array}{l}\text { Percent of } \\
\text { Total } \\
\text { Trade }\end{array}$ & $\begin{array}{l}\text { Percent of } \\
\text { Total PRC } \\
\text { Trade }\end{array}$ \\
\hline 1971 & 4.7 & 0.0 & 4.7 & -4.7 & 0.0 & - \\
\hline 1972 & 32.2 & 60.2 & 92.4 & 28.0 & 0.1 & - \\
\hline 1973 & 63.5 & 689.1 & 752.6 & 625.6 & 0.5 & - \\
\hline 1974 & 114.4 & 806.9 & 921.2 & 692.5 & 0.4 & - \\
\hline 1975 & 157.9 & 303.6 & 461.6 & 145.7 & 0.2 & - \\
\hline 1976 & 201.5 & 134.4 & 335.9 & -67.1 & 0.1 & - \\
\hline 1977 & 200.7 & 171.3 & 372.1 & -29.4 & 0.1 & 2.5 \\
\hline 1978 & 324.0 & 820.7 & $1,114.6$ & 496.7 & 0.3 & 5.4 \\
\hline 1979 & 592.3 & $1,724.0$ & $2,316.3$ & $1,131.7$ & 0.6 & 7.9 \\
\hline 1980 & $1,058.3$ & $3,754.4$ & $4,812.7$ & $2,696.1$ & 1.0 & 12.7 \\
\hline
\end{tabular}

Note: In millions of current US dollars (in the American system, 1 billion $=1,000$ million, 1 trillion $=$ 1,000 billion)

\begin{tabular}{|l|l|l|l|l|l|l|}
\hline Year & $\begin{array}{l}\text { PRC Exports to } \\
\text { US }\end{array}$ & $\begin{array}{l}\text { PRC Imports } \\
\text { from US }\end{array}$ & $\begin{array}{l}\text { Total } \\
\text { Trade }\end{array}$ & Bilateral & $\begin{array}{l}\text { China } \\
\text { Balance }\end{array}$ & Trade \\
\hline
\end{tabular}

${ }^{262}$ Barbieri. Liberal Illusion: Can Trade Promote Peace, p. 129

${ }^{263}$ Barbieri. Liberal Illusion: Can Trade Promote Peace, p. 129

${ }^{264}$ Barbieri. Liberal Illusion: Can Trade Promote Peace, p. 129

${ }^{265}$ Wang 'China's Trade Relations with the United States in Perspective', p. 174 


\begin{tabular}{|l|l|l|l|l|}
\hline 1971 & - & - & - & \\
\hline 1972 & 9.6 & 3.30 & 12.90 & 6.30 \\
\hline 1973 & 39.72 & 220.66 & 260.38 & -180.94 \\
\hline 1974 & 102.86 & 372.85 & 475.71 & -269.99 \\
\hline 1975 & 128.88 & 341.83 & 470.71 & -212.95 \\
\hline 1976 & 156.04 & 160.64 & 316.68 & -4.60 \\
\hline 1977 & 179.63 & 114.62 & 294.25 & 65.01 \\
\hline 1978 & 270.60 & 721.10 & 991.70 & -450.50 \\
\hline 1979 & 595.01 & $1,856.59$ & $2,451.60$ & $-1,261.58$ \\
\hline 1980 & 981.06 & $3,830.21$ & $4,811.27$ & $-2,849.15$ \\
\hline
\end{tabular}

Table $2^{266}$ : Sino-American Trade, 1971-1980 (Chinese Figures)

Note: In millions of current US dollars

Table $3^{267}$ : Sino-American Trade, 1981-1990 (American Figures)

\begin{tabular}{|l|l|l|l|l|l|l|}
\hline Year & $\begin{array}{l}\text { US Imports } \\
\text { from PRC }\end{array}$ & $\begin{array}{l}\text { US Exports } \\
\text { to PRC }\end{array}$ & $\begin{array}{l}\text { Total } \\
\text { Bilateral } \\
\text { Trade }\end{array}$ & $\begin{array}{l}\text { US Trade } \\
\text { Balance }\end{array}$ & $\begin{array}{l}\text { Percent of } \\
\text { Total Percent of } \\
\text { Trade }\end{array}$ & $\begin{array}{l}\text { US } \\
\text { Total PRC } \\
\text { Trade }\end{array}$ \\
\hline 1981 & $1,865.3$ & $3,602.7$ & $5,468.0$ & $1,737.4$ & 1.1 & 12.7 \\
\hline 1982 & $2,283.7$ & $2,912.1$ & $5,195.8$ & 628.4 & 1.1 & 12.7 \\
\hline 1983 & $2,244.1$ & $2,176.1$ & $4,420.2$ & -68.0 & 0.9 & 10.2 \\
\hline 1984 & $3,064.8$ & $3,004.0$ & $6,068.8$ & -60.8 & 1.1 & 11.8 \\
\hline 1985 & $3,861.7$ & $3,851.7$ & $7,713.4$ & -9.9 & 1.4 & 10.9 \\
\hline 1986 & $4,770.9$ & $3,105.4$ & $7,876.3$ & $-1,665.5$ & 1.3 & 10.5 \\
\hline 1988 & $6,293.5$ & $3,488.4$ & $9,781.8$ & $-2,805.1$ & 1.4 & 11.8 \\
\hline 1989 & $8,512.2$ & 5.022 .9 & $13,535.1$ & $-3,489.3$ & 1.7 & 13.2 \\
\hline 1990 & $11,988.5$ & $5,807.4$ & $17,795.9$ & $-6,181.1$ & 2.1 & 16.1 \\
\hline & $15,223.9$ & $4,807.3$ & $20,031.2$ & $-10,416.6$ & 2.2 & 17.6 \\
\hline
\end{tabular}

Note: In millions of current US dollars (in the American system, 1 billion $=1,000$ million, 1 trillion $=$ 1,000 billion)

Table $4^{268}$ : Sino-American Trade, 1981-1990 (Chinese Figures)

\begin{tabular}{|l|l|l|l|l|}
\hline Year & $\begin{array}{l}\text { PRC Exports to } \\
\text { US }\end{array}$ & $\begin{array}{l}\text { PRC Imports } \\
\text { from US }\end{array}$ & $\begin{array}{l}\text { Total Bilateral } \\
\text { Trade }\end{array}$ & $\begin{array}{l}\text { China } \\
\text { Balance }\end{array}$ \\
\hline 1981 & $1,505.79$ & $4,382.53$ & $5,888.32$ & $-2,876.74$ \\
\hline 1982 & $1,619.25$ & $3,716.75$ & $5,336.00$ & $-2,097.50$ \\
\hline 1983 & $1,720.17$ & $2,321.67$ & $4,041.84$ & -601.50 \\
\hline 1984 & $2,299.71$ & $3,663.38$ & $5,963.09$ & $-1,363.67$ \\
\hline 1985 & $2,651.71$ & $4,373.36$ & $7,024.96$ & $-1,721.76$ \\
\hline 1986 & $2,466.43$ & $3,527.09$ & $5,993.25$ & $-1,060.66$ \\
\hline 1987 & $2,962.66$ & $3,809.36$ & $6,772.02$ & -846.70 \\
\hline 1988 & $3,209.96$ & $5,651.93$ & $8,261.89$ & $-2,441.97$ \\
\hline 1989 & $4,410.00$ & $7,860.00$ & $12,270.00$ & $-3,450.00$ \\
\hline 1990 & $6,580.00$ & $5,190.00$ & $11,770.00$ & $-1,390.00$ \\
\hline
\end{tabular}

Note: In millions of current US dollars

Table $5^{269}$. Sino-American Trade, 1991-2009 (American Figures)

\footnotetext{
${ }^{266}$ Wang 'China's Trade Relations with the United States in Perspective', p. 174

${ }^{267}$ Wang 'China's Trade Relations with the United States in Perspective', p.179

${ }^{268}$ Wang 'China's Trade Relations with the United States in Perspective', p.179.

${ }^{269}$ Wang 'China's Trade Relations with the United States in Perspective', p.186
} 


\begin{tabular}{|l|l|l|l|l|l|}
\hline Year & $\begin{array}{l}\text { US Imports } \\
\text { from } \\
\text { PRC/World }\end{array}$ & $\begin{array}{l}\text { US Exports to } \\
\text { PRC/World }\end{array}$ & $\begin{array}{l}\text { Total US- } \\
\text { China/US- } \\
\text { World Trade }\end{array}$ & $\begin{array}{l}\text { US-China/US- } \\
\text { World Trade } \\
\text { Balance }\end{array}$ & $\begin{array}{l}\text { Percent } \\
\text { Total } \\
\text { Trade }\end{array}$ \\
\hline 1991 & $19.0 / 488.2$ & $6.3 / 421.9$ & $25.6 / 910.1$ & $-12.7 /-66.3$ & 2.8 \\
\hline 1992 & $25.7 / 532.7$ & $7.4 / 448.2$ & $33.1 / 980.9$ & $-18.3 / 84.5$ & 3.4 \\
\hline 1993 & $31.5 / 580.7$ & $8.8 / 465.1$ & $40.3 / 1,045.8$ & $-22.8 /-115.6$ & 3.9 \\
\hline 1994 & $38.8 / 663.3$ & $9.3 / 512.6$ & $48.1 / 1,175.9$ & $-29.5 /-150.6$ & 4.1 \\
\hline 1995 & $45.6 / 743.5$ & $11.8 / 584.7$ & $57.4 / 1,328.2$ & $-33.8 /-158.8$ & 4.3 \\
\hline 1996 & $51.5 / 795.3$ & $12.0 / 625.1$ & $63.5 / 1,420.4$ & $-39.5 /-170.2$ & 4.5 \\
\hline 1997 & $62.6 / 869.7$ & $12.8 / 689.2$ & $75.4 / 1,558.9$ & $-49.8 /-180.5$ & 4.8 \\
\hline 1998 & $71.2 / 911.9$ & $14.3 / 682.1$ & $85.8 / 1,594$ & $-56.9 /-229.8$ & 5.4 \\
\hline 1999 & $81.8 / 1,024.6$ & $13.1 / 695.8$ & $94.9 / 1,719.6$ & $-68.7 /-328.8$ & 5.5 \\
\hline 2000 & $100.0 / 1,218.0$ & $16.3 / 781.9$ & $116.3 / 1,199.9$ & $-83.7 /-436.1$ & 5.8 \\
\hline 2001 & $102.3 / 1,141$ & $19.2 / 729.1$ & $121.5 / 1,870.1$ & $-83.7 /-411.9$ & 6.5 \\
\hline 2002 & $125.2 / 1,161.4$ & $22.1 / 693.1$ & $147.3 / 1,854.5$ & $-103.1 /-468.3$ & 7.9 \\
\hline 2003 & $152.4 / 1,257.1$ & $28.4 / 724.8$ & $180.8 / 1,981.9$ & $-124.0 /-532.4$ & 9.1 \\
\hline 2004 & $196.7 / 1,469.7$ & $34.7 / 818.8$ & $231.4 / 2,288.5$ & $-162.0 /-650.9$ & 10.1 \\
\hline 2005 & $243.5 / 1,673.5$ & $41.8 / 906$ & $285.3 / 2,579.5$ & $-201.6 /-767.5$ & 11.1 \\
\hline 2006 & $287.8 / 1,854$ & $55.2 / 1,037$ & $343 / 2,891$ & $-232.5 /-817.3$ & 11.9 \\
\hline 2007 & $321.5 / 1,957$ & $65.2 / 1,148.2$ & $386.7 / 3,105.2$ & $-256.3 /-808.7$ & 12.5 \\
\hline 2008 & $337.8 / 2,103.6$ & $71.5 / 1,287.4$ & $409.2 / 3,391$ & $-266.3 /-816.2$ & 12.1 \\
\hline 2009 & $296.4 / 1,558.1$ & $69.6 / 1,056.9$ & $366.0 / 2,615$ & $-226.8 /-501.3$ & 14.0 \\
\hline$N 019:$ & & US & & & \\
\hline
\end{tabular}

Note: In millions of current US dollars (in the American system, 1 billion $=1,000$ million, 1 trillion $=$ 1,000 billion)

Table $6^{270}$. Sino-American Trade, 1991-2009 (China Figures)

\begin{tabular}{|l|l|l|l|l|l|}
\hline Year & $\begin{array}{l}\text { PRC Imports } \\
\text { from } \\
\text { US/World }\end{array}$ & $\begin{array}{l}\text { PRC Exports } \\
\text { to US/World }\end{array}$ & $\begin{array}{l}\text { Total China- } \\
\text { US/China- } \\
\text { World Trade }\end{array}$ & $\begin{array}{l}\text { China Trade } \\
\text { Balance with } \\
\text { US/World }\end{array}$ & $\begin{array}{l}\text { Percent of } \\
\text { Total PRC } \\
\text { Trade }\end{array}$ \\
\hline 1991 & $6.2 / 71.9$ & $8.0 / 63.8$ & $14.2 / 135.7$ & $-1.8 / 8.1$ & 10.5 \\
\hline 1992 & $8.6 / 84.9$ & $8.9 / 80.6$ & $17.7 / 165.5$ & $-0.3 / 4.4$ & 10.6 \\
\hline 1993 & $17.0 / 91.7$ & $10.7 / 104.0$ & $27.7 / 195.7$ & $6,28 /-12.2$ & 14.2 \\
\hline 1994 & $21.5 / 121.0$ & $14.0 / 115.6$ & $35.4 / 236.6$ & $7.5 / 5.4$ & 15.0 \\
\hline 1995 & $24.7 / 148.8$ & $16.1 / 132.1$ & $40.8 / 280.9$ & $8.6 / 16.7$ & 14.5 \\
\hline 1996 & $26.7 / 151.1$ & $16.2 / 138.8$ & $42.9 / 289.9$ & $10.5 / 12.3$ & 14.8 \\
\hline 1997 & $32.7 / 182.7$ & $16.3 / 142.4$ & $49.0 / 325.2$ & $16.4 / 40.4$ & 15.1 \\
\hline
\end{tabular}

${ }^{270}$ Wang 'China's Trade Relations with the United States in Perspective', p.187 


\begin{tabular}{|l|l|l|l|l|l|}
\hline 1998 & $38.0 / 183.7$ & $17.0 / 140.2$ & $55.0 / 323.9$ & $21.0 / 43.5$ & 17.0 \\
\hline 1999 & $41.9 / 194.9$ & $19.5 / 165.7$ & $61.4 / 360.6$ & $22.4 / 29.2$ & 17.0 \\
\hline 2000 & $52.1 / 249.2$ & $22.4 / 225.1$ & $74.5 / 474.3$ & $29.7 / 24.1$ & 15.7 \\
\hline 2001 & $54.3 / 266.2$ & $26.2 / 243.6$ & $80.5 / 509.8$ & $28.1 / 22.6$ & 15.8 \\
\hline 2002 & $69.9 / 325.6$ & $27.2 / 295.2$ & $97.2 / 620.8$ & $42.7 / 30.4$ & 15.7 \\
\hline 2003 & $92.5 / 438.2$ & $33.9 / 412.8$ & $126.3 / 851.0$ & $58.6 / 25.4$ & 14.8 \\
\hline 2004 & $125.0 / 593.3$ & $44.7 / 561.2$ & $169.6 / 1,154.6$ & $80.3 / 32.1$ & 14.7 \\
\hline 2005 & $162.9 / 762.0$ & $48.6 / 660.0$ & $211.5 / 1,422$ & $114.3 / 102.0$ & 14.8 \\
\hline 2006 & $203.4 / 969.0$ & $59.2 / 791.5$ & $262.7 / 1,760.4$ & $144.2 / 177.5$ & 14.9 \\
\hline 2007 & $232.7 / 1,218.0$ & $69.4 / 955.8$ & $302.1 / 2,173.8$ & $163.3 / 262.2$ & 13.9 \\
\hline 2008 & $248.4 / 1,428.6$ & $81.1 / 1,133.1$ & $329.5 / 2,561.7$ & $167.3 / 295.5$ & 12.9 \\
\hline 2009 & $220.8 / 1,201.7$ & $77.4 / 1,005.6$ & $298.2 / 2,207.3$ & $143.4 / 196.1$ & 13.5 \\
\hline
\end{tabular}

Note: In millions of current US dollars (in the American system, 1 billion $=1,000$ million, 1 trillion $=$ 1,000 billion)

Table 7. US and Chinese Trade Figure, 2010-2012 ${ }^{271}$ (US \$ million)

\begin{tabular}{|l|l|l|l|l|l|l|}
\hline & \multicolumn{3}{|l|}{ US Trade Figures } & \multicolumn{2}{l|}{ Chinese Trade Figures } \\
\hline Year & $\begin{array}{l}\text { Exports to } \\
\text { China } \\
\text { (F.A.S) }\end{array}$ & $\begin{array}{l}\text { Imports } \\
\text { from China } \\
\text { (C.V.) }\end{array}$ & $\begin{array}{l}\text { Trade } \\
\text { Balance }\end{array}$ & $\begin{array}{l}\text { Exports to } \\
\text { US (F.O.B) }\end{array}$ & $\begin{array}{l}\text { Imports } \\
\text { from } \\
\text { United } \\
\text { States } \\
\text { (C.I.F) }\end{array}$ & $\begin{array}{l}\text { Trade } \\
\text { Balance }\end{array}$ \\
\hline 2010 & 91.878 & 364.944 & -273.066 & 283.184 & 103.310 & 181.873 \\
\hline 2011 & 103.879 & 399.335 & -295.457 & 324.300 & 188.121 & 206.180 \\
\hline 2012 & 110.590 & 425.644 & -311.053 & 351.884 & 127.775 & 224.129 \\
\hline
\end{tabular}

Table $8^{272}$ : US FDI to China, 2000-2011 (US \$ million)

\begin{tabular}{|l|l|l|l|l|l|l|l|l|l|l|l|}
\hline & $\mathbf{2 0 0 0}$ & $\mathbf{2 0 0 1}$ & $\mathbf{2 0 0 2}$ & $\mathbf{2 0 0 3}$ & $\mathbf{2 0 0 4}$ & $\mathbf{2 0 0 5}$ & $\mathbf{2 0 0 6}$ & $\mathbf{2 0 0 7}$ & $\mathbf{2 0 0 8}$ & $\mathbf{2 0 0 9}$ & $\mathbf{2 0 1 0}$ \\
\hline Flow & 1,817 & 1,912 & 875 & 1,273 & 4,499 & 1,955 & 4,226 & 5,243 & 15,971 & $-7,853$ & 9,565 \\
\hline Stock & 11,140 & 12,081 & 10,570 & 11,261 & 17,616 & 19,016 & 26,459 & 29,710 & 52,521 & 49,403 & 60,452 \\
\hline
\end{tabular}

Table $9^{273}$ China's Foreign Direct Investment in the United States, 2003-2010 (US \$ million)

\begin{tabular}{|l|l|l|l|l|l|l|l|l|}
\hline & $\mathbf{2 0 0 3}$ & $\mathbf{2 0 0 4}$ & $\mathbf{2 0 0 5}$ & $\mathbf{2 0 0 6}$ & $\mathbf{2 0 0 7}$ & $\mathbf{2 0 0 8}$ & $\mathbf{2 0 0 9}$ & $\mathbf{2 0 1 0}$ \\
\hline Flow & 65.05 & 119.93 & 231.82 & 198.34 & 195.73 & 462.03 & 908.74 & 1308.29 \\
\hline Stock & 502.32 & 665.20 & 882.68 & $1,237.87$ & $1,880.53$ & $2,389.90$ & $3,338.42$ & $4,873.99$ \\
\hline
\end{tabular}

${ }^{271}$ Martin. 'What's the Difference? Comparing US and Chinese Trade Data', p.2.

272 'Report to Congress of the US-China Economic and Security Review Commission' (2011), p. 51

273 'Report to Congress of the US-China Economic and Security Review Commission' (2011), p. 56 


\section{BIBLIOGRAPHY}

Andrew, Little, Mann, Nicholson, Rosenau, Sylvester, Wallerstein, and Waever. 'International Theory: Positivism and Beyond' in Smith, Booth and Zalewski (ed.). Legacies. (Cambridge: Cambridge University Press, 1996), pp. 47-128.

Baldwin, David, A. 'Interdependence and power: a conceptual analysis'. International Organization, Vol. 34, No. 4, Autumn 1980, pp.471-506

Barbieri, Katherine 'Economic Interdependence: A Path to Peace or a Source of Interstate Conflict?', Journal of Peace Research, Vol. 33, No. 1 (Feb., 1996), pp. 29-49. Barbieri 'Economic Interdependence: A Path to Peace or a Source of Interstate Conflict?', p.32-33

Barbieri, Katherine. The Liberal Illusion: Does Trade Promote Peace? (University of Michigan Press, 2002)

Barbieri, Katherine. 'The Liberal Illusion: Does Trade Promote Conflict'. (The University of Michigan Press, 2005).

Beckley, Michael. 'China's Century? Why America's Edge Will Endure', International Security, Vol. 36, No. 3 (Winter 2011/12), pp. 41-78.

Branstetter, Lee and Foley, C. Fritz. 'Facts and Fallacies about US FDI in China'. National Bureau of Economic Research. Working Paper 13470, 2007.

Breslin, Shaun. 'China and the Crisis: Global Power, Domestic Caution and Local Initiative' Contemporary Politics, Vol. 17, No.2, 2011, pp. 185-200.

Brooks, Stephen, G. 'The Globalization of Production and the Changing Benefits of Conquest'. Journal of Conflict Resolution, Vol. 43, No. 5,1999, pp.646-670.

Chan, Steve. 'Is there a Power Transition between the US and China? The Different Faces of National Power'. University of California Press. Vol. 45, No.5, September/October 2005, pp.687-701.

Cai, Feina. 'Absolute and Relative Gains in the Real World'. E-International Relations, 2011. 
Chow, Gregory, C. 'Economic Reform and Growth in China'. Annals of Economic and Finance, Vol.5, 2004, pp. 127-152.

Chen-Yuan Tung, 'The Impact of Bilateral Economic Interdependence on USChina Relations'. Retrieved from:

http://www3.nccu.edu.tw/ ctung/Documents/W-B-a-7.doc (5 July 2013).

Crescenzi, Mark J. C. Economic Interdependence and Conflict in World Politics. (University of North Carolina, Chapel Hill, 2002).

Dumbaugh, Kerry. 'China-US Relations: Current Issues and Implications for US Policy'. Congressional Research Service, 2009, 7-5700, R40457

Ferguson, Niall and Schularick, Moritz. 'Chimerica and the Global Asset Market Boom'. International Finance, Vol. 10, No.3, 2007, pp.215-239.

Friedberg, Aaron, L. 'The Future of US-China Relations: Is Conflict Inevitable?' International Security, Vol.30, No.2 (Autumn, 2005), pp. 7-45.

Friedberg, Aaron, L. 'A Contest for Supremacy: China, America, and the Struggle for Mastery in Asia'. Roots of Rivalry (New York: W. W. Norton \& Company, 2011), pp. $36-58$.

Grieco, Joseph. M. 'Anarchy and the Limits of Cooperation: A Realist Critique of the Newest Liberal Institutionalism'. International Organization, Vol. 42, No. 3, Summer 1988, pp. 485-507.

Hopkins, Katy (2012). 'International Students Continue to Flock to US Colleges, Grad Schools'. US News. Retrieved from:

http://www.usnews.com/education/bestcolleges/articles/2012/11/12/international-students-continue-to-flock-to-us-colleges-gradschools (18 July 2013)

$\mathrm{Hu}$, Zuliu and Khan, Mohsin, S. 'Why is China Growing So Fast? International Monetary Fund, Washington, D. C, 1997.

Islam, Akm, Khairul. 'The Post-Cold War US-China Relations: Win-Win or Zero-Sum Game, Asian Affairs, Vol.28, No. 2, April-June 2006, pp.24-45.

Keohane, Robert, O. and Nye, Joseph S. Jr. 'Power and Interdependence'. Interdependence as an Analytic Concept. (Longman Classics and Political Science, 2001). 
Keohane, Robert, O. and Nye, Joseph S. Jr. 'Power and Interdependence'. Interdependence as an Analytic Concept. (Longman Classics and Political Science, 2001).

Kugler, Jacek and Tamen, Ronald. 'Regional Challenge: China's Rise to Power' Lardy, Nicholas, R. 'China: The Great New Economic Challenge?' . Retrieved from:

www.piie.com/publications/chapters_preview/3802/4iie3802.pdf (9 July 2013)

Liew, Leong. H. 'US Trade Deficits and Sino-US Relations', Department of International Business \& Asian Studies, Griffith University, Queensland, Australia, 2010., pp.4-8.

Mansfield, Edward, D. and Pollins, Brian, M. 'Interdependence and Conflict: An Introduction'; Crescenzi, Mark J. C. Economic Interdependence and Conflict in World Politics. (University of North Carolina, Chapel Hill, 2002)

Mansfield, Edward, D. and Pollins, Brian, M. 'Interdependence and Conflict: An Introduction', p.11. Retrieved from:

www.press.umich.edu/pdf/0472098276-intro.pdf (2 July 2013)

Martin, Michael, F. What's the Difference? Comparing US and Chinese Trade Data. Congressional Research Service, CRS Report for Congress, 2013.

Morrison, Wayne M. 'China-US Trade Issues'. Congressional Research Service, 2013, 7-5700, RL 33536.

Morrison, Wayne, M. and Labonte, Marc. 'China's Holdings of US Securities: Implications for the US Economy'. Congressional Research Service 7-5700, RL 34314, 2012, pp.4-8.

Muthiad, Alagappa. 'A Changing Asia: Prospects for War, Peace, Cooperation, and Order' Political Science, Vol. 63, No. 2, 2011, pp. 155:185.

Nye, Joseph, Samuel. Jr. 'American and Chinese Power after the Financial Crisis'. The Washington Quarterly. Vol. 33, No. 4, 2010, pp. 143-153.

'Obama, Xi Emphasize Importance of U.S.-China Relationship'. US Department of Defense, 2013. Retrieved from:

http://www.defense.gov/news/newsarticle.aspx?id=120242 (13 July 2013) 
Obama, Barack . 'US-China Policy Under an Obama Administration'. AmchamChina's China Brief, 2008.

Pape, 'Empire Falls: First Draft of History'. The National Interest, JanuaryFebruary 2009, pp.21-34.

Rapkin, David, P. and Thompson, William, R. 'Will Economic Interdependence Encourage China's and India's Peaceful Ascent? Strategic Asia 2006-7.

Rajan, Ramkishen, S. and Beverinotti, Javier. 'China, Currencies and the Financial Balance of Terror'. Policy Brief Series, Issue 2, 2011.

Ravenhill, J. 'Security Politics in the Asia-Pacific: A regional-global'. The economics-security nexus in the Asia-Pacific Region. (Cambridge: Cambridge University Press, 2009)

Ryan, Sean. 'Why is China so important to the U.S. economy?' Hubpages. Retrieved from:

http://kapitall.hubpages.com/hub/Why-is-China-so-Important-to-the-US-

Economy (25 August 2012)

Sengupta, Jayshree. 'Economic Relations between the US and Two Asian Giants' in a Rasgotra, M. (ed). (New Delhi: Sage Publication, 2007), pp.103-120

Shambaugh, David. 'Facing Reality in China Policy'. Foreign Affairs, Vol.80, No. 1 (Jan-Feb, 2001), pp.50-64.

Shirk, Susan., L. China: Fragile Superpower. (New York: Oxford University Press, 2007).

Song, Liang. 'China's Rapid Growth and Development: An Historical and International Context' (2010). paftad.org/.../02_SONG,\%20Ligang\%20\%20Interl\%20dim\%20of\%20g (5 July 2013).

Sutter, Robert, G. US-Chinese Relation: Perilous Past, Pragmatic Present (Maryland: Rowman \& Littlefield Publisher, Inc, 2010)

Swaine, Michael, D. 'America's Challenge: Engaging a Rising China in the Twenty-First Century' (Washington: Carnegie Endowment, 2011).

Tellis, Ashley. J and Wills, Michael (ed.). 'Trade, Interdependence, and Security in Asia'. Strategic Asia 2006-07. (Washington: The National Bureau of Asian Research). 
Tellis, Ashley, J. 'Trade, Interdependence and Security' in Tellis, Ashley, J and Wills, Michael (ed.). Trade, Interdependence and Security in Asia. (Washington: The National Bureau of Asian Research, 2006) pp.1-25.

VanHook, Lauren. 'China in the Balance: Can Economic Interdependence Bring Stability to South Asia'. Retrieved from

www.moreheadstate.edu/uploadedFiles/Sites/Main_Sites/.../china.pdf (17 July 2013), p. 13

Wang, Dong. 'China's Trade Relations with the United States in Perspective'. Journal of Current Chinese Affairs, Vol. 39. No.3, 2010, pp. 165-210.

Wang, Jianhua and Li Yunlu. 'China-US Trade War No Good for Anyone'. People's Daily Online, 2011. Retrieved from:

Wang, Jisi. 'China' Search for Stability with America'. Foreign Affairs. Vol.84, No.5, Sep.-Oct. 2005, pp.39-48.

White, Huge. 'The China Choice: Why America Should Share Power'. A Hard Choice. (Collingwood: Black Inc., 2012).

World Trade Organization, 'Trade Patterns and Global Value Chains in East Asia: From Trade in Goods to Trade in Tasks', pp. 60-70

Xinchun, Niu. 'Sino-US Relations: Dependence and Fragility'. China Institutes of Contemporary International Relations, 2010. Retrieved from:

http://www.chinausfocus.com/library/think-tank-resources/chinalib/foreign_policy/cicir-sino-us-relations-dependence-and-fragility-february-2010/ (8 July 2013)

Young, Terry. 'US and China Economic Relationship at a Crossroad'. China US Focus, 2012. Retrieved from:

http://www.chinausfocus.com/slider/us-and-china-economic-relationship-at-acrossroad/ (18 July 2013)

Zhiqun, Zhu. 'Power Transition and US-China Relations: Is War Inevitable?' Journal of International and Area Studies, Vol. 12, No, 1, 2005, pp. 1-24.

Zhao, Qian. 'US says yuan still undervalued'. Global Times, 2013.

'Trade Deficit: Good or Bad?'. Retrieved from: 
http://www.infoplease.com/cig/economics/trade-deficits-bad-good.html (12 July 2013)

(2012). 'US Congressional District Exports to China: 2002-11 $112^{\text {th }}$ Congress'. The US-China Business Council. Retrieved from: https://www.uschina.org/public/exports/2000_2011/files/US_Cong_Dist_Exports _2000-11.pdf (August 25, 2012) 